\title{
Oral Microbiota: A Major Player in the Diagnosis of Systemic Diseases
}

\author{
Charlotte Thomas ${ }^{1,2,3, *,+}$, Matthieu Minty ${ }^{1,2,3, *, \dagger}$, Alexia Vinel ${ }^{1,2,3}$, Thibault Canceill ${ }^{2,3,4}$, Pascale Loubières ${ }^{1,2}$, \\ Remy Burcelin 1,2, Myriam Kaddech ${ }^{2,3}$, Vincent Blasco-Baque ${ }^{1,2,3,+}$ and Sara Laurencin-Dalicieux $2,3,5,+\mathbb{D}$
}

1 INSERM UMR 1297 Inserm, Institut des Maladies Métaboliques et Cardiovasculaires (I2MC), Avenue Jean Poulhès 1, CEDEX 4, 31432 Toulouse, France; alexia.vinel@inserm.fr (A.V.); pascale.loubieres@inserm.fr (P.L.); remy.burcelin@inserm.fr (R.B.); vincent.blasco@inserm.fr (V.B.-B.)

2 Faculté de Chirurgie Dentaire, Université Paul Sabatier III (UPS), 118 Route de Narbonne, CEDEX 9, 31062 Toulouse, France; thibault.canceill@sfr.fr (T.C.); myriamkaddech@hotmail.com (M.K.); laurencin.s@chu-toulouse.fr (S.L.-D.)

3 Service d'Odontologie Rangueil, CHU de Toulouse, 3 Chemin des Maraîchers, CEDEX 9, 31062 Toulouse, France

4 UMR CNRS 5085, Centre Interuniversitaire de Recherche et d'Ingénierie des Matériaux (CIRIMAT), Université Paul Sabatier, 35 Chemin des Maraichers, CEDEX 9, 31062 Toulouse, France

5 INSERM UMR 1295, Centre d'Epidémiologie et de Recherche en Santé des Populations de Toulouse (CERPOP), Epidémiologie et Analyse en Santé Publique, Risques, Maladies Chroniques et Handicaps, 37 Allées Jules Guesdes, 31000 Toulouse, France

* Correspondence: charlotte.thomas@inserm.fr (C.T.); matthieu.minty@inserm.fr (M.M.); Tel.: +33-5-61-32-56-12 (C.T. \& M.M.); Fax: +33-5-31-22-41-36 (C.T. \& M.M.)

check for updates

Citation: Thomas, C.; Minty, M.; Vinel, A.; Canceill, T.; Loubières, P.; Burcelin, R.; Kaddech, M.;

Blasco-Baque, V.;

Laurencin-Dalicieux, S. Oral Microbiota: A Major Player in the Diagnosis of Systemic Diseases. Diagnostics 2021, 11, 1376. https: / / doi.org/10.3390/diagnostics11081376

Academic Editor: Rosa Del Campo

Received: 15 July 2021

Accepted: 28 July 2021

Published: 30 July 2021

Publisher's Note: MDPI stays neutral with regard to jurisdictional claims in published maps and institutional affiliations.
+ These authors contributed equally to this work.

\begin{abstract}
The oral cavity is host to a complex and diverse microbiota community which plays an important role in health and disease. Major oral infections, i.e., caries and periodontal diseases, are both responsible for and induced by oral microbiota dysbiosis. This dysbiosis is known to have an impact on other chronic systemic diseases, whether triggering or aggravating them, making the oral microbiota a novel target in diagnosing, following, and treating systemic diseases. In this review, we summarize the major roles that oral microbiota can play in systemic disease development and aggravation and also how novel tools can help investigate this complex ecosystem. Finally, we describe new therapeutic approaches based on oral bacterial recolonization or host modulation therapies. Collaboration in diagnosis and treatment between oral specialists and general health specialists is of key importance in bridging oral and systemic health and disease and improving patients' wellbeing.
\end{abstract}

Keywords: oral microbiota; systemic disease; dysbiosis; periodontitis; endotoxemia; inflammation

\section{Introduction}

The oral cavity is host to a complex microbial group, the oral microbiota, composed mainly of bacteria but also includes viruses, protozoans, fungi, archaea, phages, and ultrasmall bacteria belonging to the candidate phyla radiation group [1-3]. Oral microbiota, developed from the first minutes of a child's life, is composed of more than 500 different bacterial species $[4,5]$. Its exact composition varies greatly from one individual to another as it depends on several factors, such as age, diet, and lifestyle habits (such as smoking and physical activity) [6]. Present in a physiological state, these bacteria cohabit with the human body in a state of symbiosis. There are two equilibriums; one between the proliferation of the different species and the immune capacities of the host and the other, between the bacterial species themselves. In the event of dysbiosis, i.e., a breakdown in this homeostasis, one or more types of microorganisms proliferate and take over-at least temporarily - the immune system [7]. Various oral pathologies can then occur and 
will depend on the type of bacterial imbalance [8]. However, the oral microbiota does not only have a local function. We now know that our mouth, through its microbiota, communicates intensely with our whole body [3]. Indeed, oral dysbiosis causes a localized inflammatory state in the oral sphere that can contribute to the maintenance of chronic low-grade systemic inflammation [9]. This can lead to the development or aggravation of systemic pathologies, sometimes with a significant degree of morbidity. The identification of bacteria responsible for these relationships between the oral cavity and the rest of the body is therefore of major interest. The oral microbiota thus becomes a marker of our general health via its systemic activity. The aim of this review is to describe the role of oral microbiota and its bacterial effectors on our general health. The oral cavity and its microbiota play an important role in the diagnosis of an individual's health status and may also give rise to new preventive and therapeutic approaches [10].

\section{Oral Microbiota}

The oral cavity is the second-largest microbiota reservoir in the body and has been the subject of intense study for several years [11]. The accessibility of the site has made the oral microbiota one of the best-known bacterial communities in the human body, with more than 500 different species identified in adults. Even if the maternal microbiota already plays an important role in the neurodevelopment of the fetus before birth [12,13], the acquisition of the microbiota begins in the first minutes of life through direct contact with the maternal microbiota (skin, vagina, and mouth) [14]. The child's environment is also essential to the construction of its microbiota which is not solely acquired through heredity [4].

The different ecological niches that make up the oral microbiota consist mainly of hard and soft tissues $[15,16]$. Saliva has a major influence on the oral microbiota and participates in maintaining oral homeostasis [17]. It is essential in mechanical cleansing, has a buffering power to maintain a physiological $\mathrm{pH}$ and antimicrobial properties through its various nonspecific immune components (immunoglobulin A, lysozyme, lactoferrin, peroxidase system, histidine-rich proteins, etc.). The composition of saliva plays a determining role on the microbiota through a cascade of mechanisms linked to the molecules in suspension, which condition the composition of the biofilm. The latter allows the attachment of bacteria to oral surfaces. Salivary components such as glycoproteins are a source of nutrition to ensure the growth of bacteria present in the mouth $[17,18]$. All these bacteria act synergistically, at very low concentrations, allowing a complex balance between the surrounding microbiota and the host's oral cavity. An insufficient salivary flow can easily lead to dysbiosis.

Bacteria are present in the mouth in two forms: either in a planktonic state, as in saliva, or in a biofilm as in the dental plaque. Bacteria present in planktonic form circulate freely in the oral environment, whereas dental plaque is the result of the heterogeneous accumulation of aerobic and anaerobic bacteria that form an adherent deposit on the surface of teeth and oral mucosa [19]. Dental surfaces are covered with an organic film called the Acquired Exogenous Pellicle (AEP), which protects teeth from mechanical and acidic aggressions but can also condition the tooth surface to promote further attachment of bacteria as part of the biofilm developmental process. Indeed, the planktonic bacteria present in saliva can adhere to the AEP in a reversible way by electrostatic and Van Der Waals forces or in an irreversible way by ionic or covalent bonds. The first step in the creation of a biofilm is the irreversible adhesion of pioneer bacteria such as Streptococcus gordonii, Streptococcus oralis, or Streptococcus mitis to the AEP, which then proliferates. Secondly, these pioneer bacteria allow the aggregation of new bacteria called late or secondary colonizers [20]. As the biofilm matures, an equilibrium is created between each bacteria present. Microbial dysbiosis can occur due to local and systemic diseases resulting in a gradual shift toward bacteria with specific profiles. 
Oral microbiota dysbiosis is at the origin of two major oral pathologies: caries and periodontitis. However, these two pathologies have different profiles [7]. Caries are responsible for the destruction of the tooth's hard tissues. They are caused by salivary dysbiosis (reduction of the bacterial diversity) resulting from a disturbed supra-gingival biofilm associated with an excess of sugar consumption and/or poor oral hygiene (factors of dysbiosis). This imbalance leads to a modification in the biofilm composition characterized by an increase in Grampositive bacteria and acidification of the medium [21,22]. The main pathogens increased are Streptococcus mutans, Actinomyces, and Lactobacillus. Bifidobacterium spp., Scardovia spp., and Candida albicans are also found in greater quantities [23-25]. This increased acidification is accompanied by a loss of diversity and a reduction in the level and metabolic activity of beneficial bacteria, which prefer to grow at neutral $\mathrm{pH}$. Periodontitis is an oral disease resulting from periodontal dysbiosis associated with a deleterious immuno-inflammatory reaction of the host, leading to the progressive and irreversible destruction of the dental attachment system (the periodontium) and ultimately causing tooth loss. In contrast to the rest of the oral cavity, the microorganisms that develop in the sulcus and adhere to the root surface evolve in an environment that is less rich in oxygen and more protected from shear forces than those found at the supra-gingival level. Periodontal dysbiosis is characterized by an increase in the proportion of Gram-negative anaerobic bacteria historically described in 1979 as belonging to Socranski's "red complex": Treponema denticola (Td), Porphyromonas gingivalis (Pg), Tannerella forsythia (Tf), and Fusobacterium nucleatum (Fn) [26]. Prevotella intermedia (Pi), Dialister spp., and Selenomonas spp. are also found in abundance in periodontitis, and the high number of spirochetes seems to be associated with the severity of periodontal destruction [27-30]. However, metagenomic sequencing has made it possible to highlight new concepts concerning periodontal dysbiosis associated with periodontitis. This dysbiosis is the result of a qualitative and quantitative modification of a polymicrobial community, including commensal and pathogenic bacteria [31]. At the periodontal level, dysbiosis comes more from a change in dominant species than from de novo bacterial colonization. Contrary to what is found at the intestinal level, periodontitis is associated with an increase in the diversity of its microbiota [32-34]. This greater diversity is thought to be the result of the additional nutrient supply from the destruction of surrounding tissues and the physical increase in the size of the periodontal pocket lesion $[7,28]$.

\section{Physiopathologic Mechanisms of Dysbiotic Oral Microbiota and Systemic Inflammation during General Diseases}

Recent data from the scientific literature suggest that there is a link between the development and/or aggravation of certain systemic pathologies and the occurrence of an imbalance in the oral flora [7]. These diseases have in common a pathophysiological mechanism based on the maintenance of a systemic inflammatory state (low-grade inflammation) whose resolution or stabilization is not possible in the presence of dysbiosis in the oral microbiota. Some authors also suggest that dysbiotic oral microbiota-causing microorganisms could circulate systemically or release part of their constituents into the bloodstream and thus cause complications away from their original site of proliferation. Bacterial meta factors are all the bacterial parts that have an activity of either virulence or activation of the immune system during physiology and physiopathology (for example, lipopolysaccharide (LPS), Flagellin, and teichoic acid). One of the main mediators of this immuno-inflammatory disorder is LPS, which is an endotoxin and a major virulence factor of Gram-negative bacteria. LPS is an example since it is likely to migrate to different organs (liver, muscles, heart, etc.) and trigger inflammatory reactions there [35]. Indeed, bacteria or their components, such as LPS present on the outer membrane of Gram-negative bacteria, are a continuous source of inflammation and infection which cross the epithelial barrier, arrive in the bloodstream, and reach various organs of the body. The main cause of this bacterial translocation is oral microbiota dysbiosis. That is to say, a loss of the balance of the salivary bacterial composition due to an excess of Gram-negative or Gram-positive bacteria or virulence factors (LPS, Flagellin, teichoic acid). Oral bacteria or meta factors activate innate immune defenses via Pathogen-Associated Molecular Patterns (PAMP) 
recognized by Pattern Recognition Receptors (PRR) of innate immune cells. PAMPs are represented by different surface molecules such as teichoic acid (Gram-positive specific) or LPS (Gram-negative specific). PRRs include a group of receptors called Toll-Like Receptor (TLR) [36]. The interaction between TLRs and PAMPs leads to the activation of the MyD88 (Myeloid Differentiation protein 88) signaling pathway and then that of the transcription factor NF-kappa B (NF-kB), inducing a generalized inflammatory response with the synthesis of a variety of pro-inflammatory mediators, such as Tumor Necrosis Factor $\alpha$ (TNF- $\alpha$ ) and interleukins.

Figure 1 represents the different possible pathways (by bacterial translocation in the blood) responsible for an increase in pro-inflammatory cytokines in systemic diseases resulting from oral microbiota dysbiosis. The transduction of an inflammatory signal to the nucleus of cells requires a succession of phosphorylation chain reactions catalyzed by protein kinases. Activation of the inflammasome is carried out according to several pathways, those of MAPK (Mitogen-Activated Protein Kinases), IKKs (Inhibitor of Kappa B Kinases), and those of JAK/STAT (Janus Kinase and Signal Transducers and Activators of Transcription). The dissemination throughout the body of these oral bacteria or their components (LPS) is at the origin of a modification of the bacterial balance and, therefore, the microbiota of other organs. Several studies have shown other ways of translocation of these oral bacteria by different processes such as ingestion (intestinal microbiota), inhalation (pulmonary microbiota), or sexual intercourse (vaginal microbiota). This shows the link between the oral microbiota and the different microbiota of the organism at the origin of various systemic pathologies described below.

In fact, oral microbiota and its balance play a major role in an individual's general homeostasis. Any disruption leads to an increase in certain bacterial species, especially Gram-negative ones, associated with the massive production of pro-inflammatory cytokines, which causes or maintains chronic low-grade inflammation. In this review, we discuss the role that dysbiotic oral microbiota may have on different systemic pathologies: metabolic diseases, cardiovascular diseases, respiratory diseases, rheumatoid arthritis, adverse pregnancy outcomes, inflammatory bowel diseases, Alzheimer's disease, autism spectrum disorders, and oral mucosal diseases (Figure 2). 


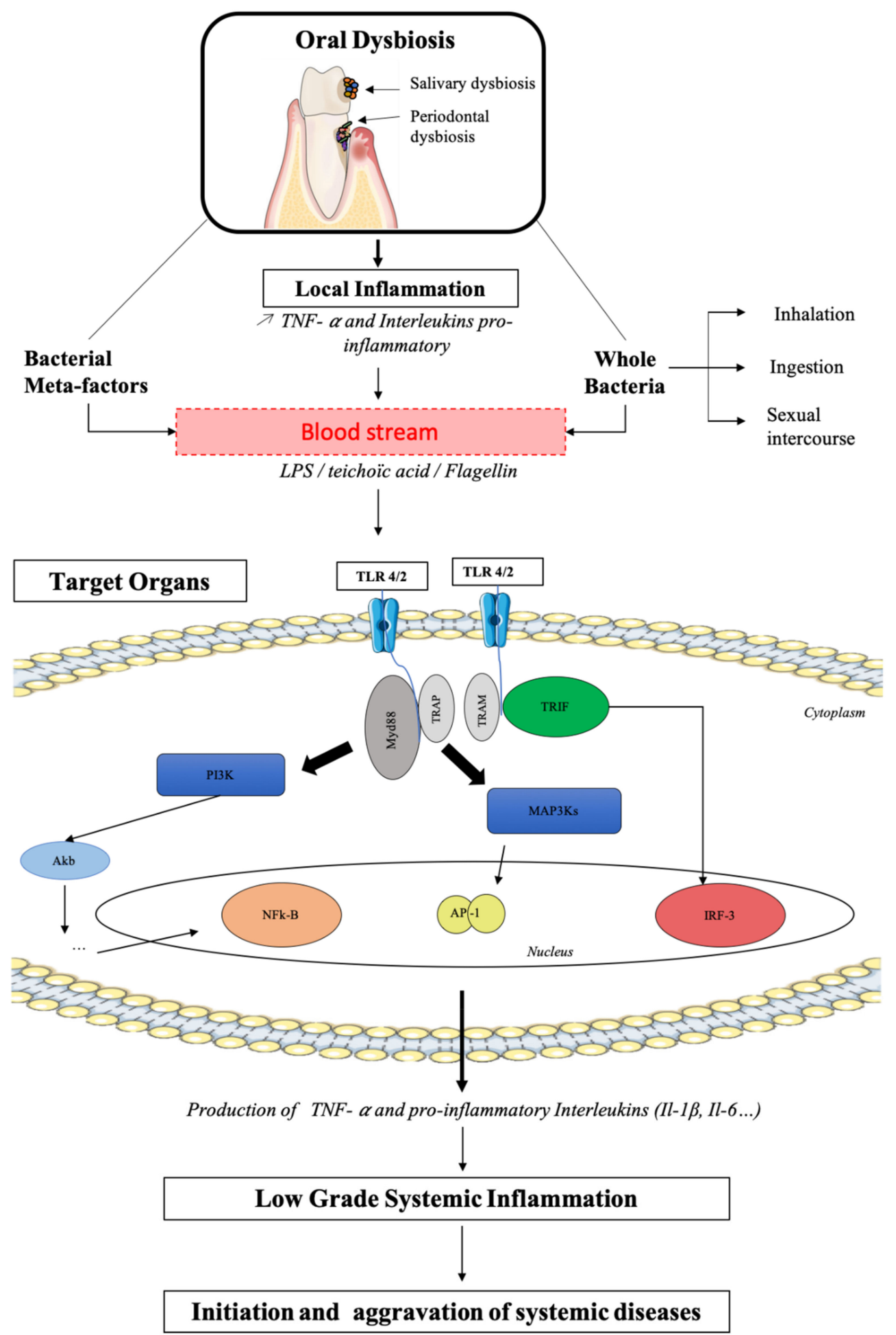

Figure 1. Possible physiopathological mechanisms linking oral dysbiosis to systemic diseases. 


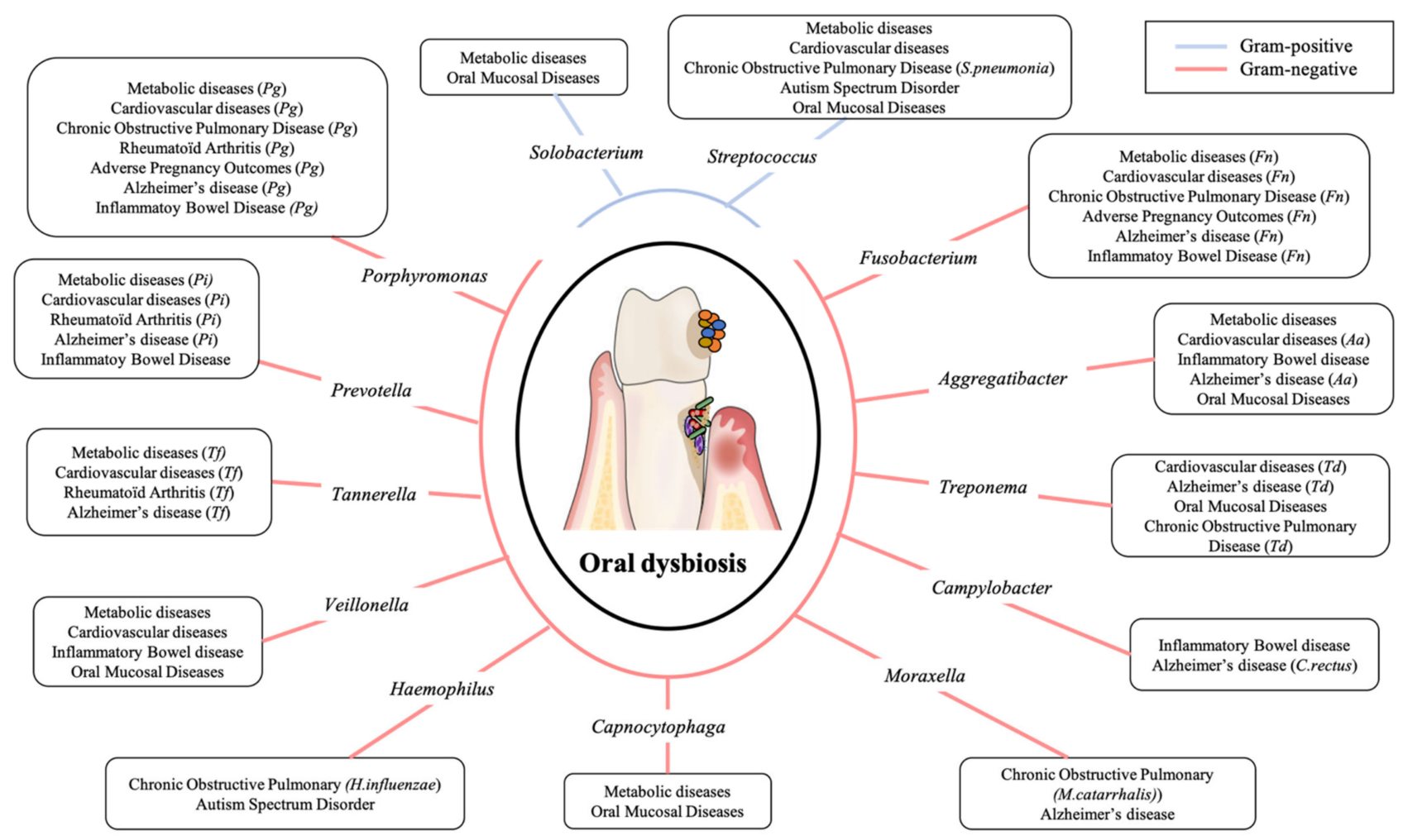

Figure 2. Principal oral pathogens implicated in systemic diseases.

\subsection{Metabolic Diseases}

Many pathologies are likely to be influenced by this low-grade inflammation. Most of them are represented by the so-called metabolic diseases, which affect the cellular functions of energy production and storage, or even in a broader sense by the "metabolic syndrome" (MetS). This corresponds to a combination of at least three manifestations among obesity, hypertriglyceridemia, high blood pressure, hyperglycemia, and reduced levels of high-density lipoproteins (HDL). Many studies have investigated the role of oral microbiota in these metabolic diseases [37]. At the epidemiological level, there is a positive association between periodontal disease and metabolic pathologies: patients with MetS have a higher risk of developing periodontitis; conversely, patients with periodontitis have a higher risk of suffering from MetS [37-39]. However, the molecular and microbiological mechanisms responsible for these clinically identified associations are still poorly understood [40,41]. The local inflammation associated with oral dysbiosis contributes to maintaining/aggravating a significant metabolic, inflammatory state throughout the body [37] and can cause insulin resistance, inflammation, vascular, and metabolic disorders. Conversely, the lack of recovery from metabolic symptoms maintains the pathological state at the oral level [42].

Diabetes is the metabolic disease whose relationship with oral microbiota has been the most extensively explored. Diabetes is a chronic metabolic disorder defined by fasting hyperglycemia and is due to a deficit in insulin secretion by pancreatic $\beta$-cells of autoimmune origin for type 1 diabetes (T1D) or decompensated insulin resistance for type 2 diabetes (T2D) [43,44]. In 2019, the number of people diagnosed with diabetes worldwide was 463 million, or $6 \%$ of the world's population. Interestingly, $80 \%$ of T2D could be avoided with a healthier diet and regular exercise [45]. However, in recent years, despite the management of these risk factors, the number of diabetics continues to rise, suggesting that there are other risk factors for diabetes, such as oral and gut dysbiosis [46,47].

The bidirectional link between diabetes and periodontitis has been demonstrated with inflammation as a common mediator [48], making periodontitis the sixth complication of T2D [49] and also suggesting that the "motor" of this pathology could be chronic low-grade 
inflammation [50], which is itself the result of oral microbiota dysbiosis. Differences in the oral and periodontal microbiota were found in diabetic subjects compared to healthy subjects [44,47,51]. A significant increase in the genera Aggregatibacter, Neisseria, Gemella, Eikenella, Selenomonas, Actinomyces, Capnocytophaga, Fusobacterium, Veillonella, and Streptococcus was observed in people with diabetes $[47,52]$. In addition, the involvement of oral pathogens such as $P g$ has been demonstrated in insulin resistance [53]. Indeed, high levels of TNF- $\alpha$ and Interleukin-6 (IL-6) (produced by periodontal macrophages in the presence of $P g$ ) increase the permeability of the epithelial barriers of the oral cavity [54] and thus favors the passage of Gram-negative bacteria and their virulence factors such as LPS into the bloodstream. In addition to the inflammatory state this causes in the organs, LPS are also responsible for inhibiting the transduction of insulin receptor-initiated signaling pathways and thus the development of insulin resistance [55]. Furthermore, periodontal treatment could reduce glycated hemoglobin $(\mathrm{HbA} 1 \mathrm{c})$ levels by up to $0.4 \%$ in T2D patients [56]. Also, oral microbiota can influence the progression of diabetes [57], and some oral hygiene measures, such as overuse of mouthwashes, can even have a detrimental effect on the progression of diabetes [58]. Nonetheless, many mechanisms on this two-dimensional interaction still remain to be elucidated.

The link between gut microbiota and obesity is already established, and numerous studies now focus on the link with the oral microbiota [59-62]. Literature has described that, as with the intestinal microbiota, there is a modification of the oral microbiota in obese people with an increased Firmicute/Bacteroides ratio [63]. Several authors have found differences in the composition of the oral microbiota between obese and normal-weighted subjects with a particular increase in certain genera and species in obese subjects: Peptostreptococcus, Solobacterium, Selenomonas noxia, $P g$, Pi, and Tf [63-67]. Recently we showed that obese people present an increased periodontal risk associated with an increase of Capnocytophaga present in the oral microbiota. Moreover, we showed that sex/gender plays a role in the oral microbiota signature of obesity in subjects with periodontitis: obese females were characterized by an increase in the Streptococcus genus compared to obese males, where the Neisseria genus was increased [68]. Even if the positive association between obesity and periodontitis has been demonstrated in numerous clinical and epidemiological studies, the causal link between oral microbiota and obesity remains to be clarified. Finally, obesity could lead to dyslipidemia and high blood pressure, which in return induce cardiovascular diseases.

\subsection{Cardiovascular Diseases}

According to the World Health Organization (WHO), cardiovascular diseases (CVD) are the first cause of death worldwide, and deaths from cardiovascular and circulatory diseases are continuously rising, partly due to population growth and aging [69,70]. An estimated 17.9 million deaths per year are attributable to cardiovascular diseases, or 32\% of global mortality [71]. There are many risk factors for cardiovascular diseases such as gender, age, smoking, dyslipidemia, hypertension, insulin resistance, and overweight and obesity [71-73]. However, despite the management of these factors, the mortality rate continues to rise associated with inter-individual variability in the risk of unexplained cardiovascular mortality and morbidity, which leads to the search for new risk factors. An increasingly studied risk factor is the immuno-inflammatory axis [74], and oral microbiota dysbiosis is a major risk factor in the development of cardiovascular disease [75].

One of the main causes of cardiovascular disease is the development of atherosclerosis under the influence of environmental and genetic factors. Atherosclerosis results from the accumulation of low-density lipoproteins (LDL) in the vascular wall, where they undergo oxidation, causing endothelial dysfunction [76]. Endothelial cells then allow the transmigration of circulating inflammatory cells, monocytes, that differentiate into macrophages within the subendothelial space where they phagocyte the oxidized LDL, becoming foamy cells. Then, nearby vascular smooth-muscle cells migrate to the lesion site and synthesize a protein matrix, forming a fibrous cap above the thrombogenic lipidic core. The more the plaque grows, the narrower the vessel lumen becomes, and in case of plaque 
rupture, the exposed lipidic core activates platelets leading to a thrombus able to block the blood flow in situ or downstream completely. Atherosclerosis is thus the main cause of myocardial infarction, coronary heart disease, stroke, and peripheral artery disease [76].

The first to raise the link between myocardial infarctions and poor oral health were Mattila et al. in 1989 [77]. Since then, numerous studies have concluded a positive association between periodontal diseases and CVD independently of their common risk factors (smoking, age, diabetes) [75,78-81]. Moreover, periodontal treatment has been shown to have beneficial effects on cardiovascular biochemical parameters such as endothelial function and C-Reactive Protein (CRP) levels [82-85]. The mechanisms linking periodontitis and CVD are both direct, via bacterial invasion, and indirect, via inflammation. Indeed, several periodontal pathogens have been identified in the atheromatous plaque, such as $\mathrm{Pg}$, Aggregatibacter actinomycetemcomitans $(\mathrm{Aa}), \mathrm{Tf}, \mathrm{Pi}, \mathrm{Td}$, and $\mathrm{Fn}$, [86-91]. Koren et al. have demonstrated the presence of oral bacteria DNA (Chryseomonas, Veillonella, and Streptococcus, mainly) on samples of atheromatous plaques and were able to establish a correlation between the measured quantity of some of these DNAs and the significant quantity of the corresponding bacteria in the oral cavity of patients [92]. Pg DNA has also been detected in the cardiac valves of patients with CVD and deep periodontal pockets and even in healthy vascular tissues. $P g$ is the most abundant specie in patients with atherosclerosis after bypass surgery $[93,94]$. In vivo studies showed that the administration of periodontal pathogens to different mice models has notable vascular effects: increased vascular reactivity, smooth muscle cells proliferation and aortic plaque development with $\mathrm{Pg}$ [95-97], arterial invasion and reduced nitric oxide levels with $T d$ [98], higher levels of inflammatory cytokines such as IL-6 and CRP, LDL and atherosclerotic lesion progression with Fn [99]. Moreover, polymicrobial infection with $P g, T d, T f$, and $F n$ is associated with accelerated atherosclerosis in vivo $[100,101]$. Recent studies showed that $P g$ is able to increase vascular permeability and cause vascular damages via, respectively, its outer membrane vesicles and surface-expressed gingipains in vitro and in vivo in a zebrafish model [102]. Also, Pussinen et al. found that coronary heart disease is more common in people who have anti- $P g$ antibodies compared to those who do not, suggesting that periodontal infection or the host's response to anti- $P g$ infection could play a role in the pathogenicity of coronary heart disease $[103,104]$.

The second mechanism linking periodontitis and CVD involves the increased inflammatory cytokines systemic levels occurring in both pathologies. The high levels of Interleukin-1 $\beta$ (IL-1 $\beta$ ), IL-6, Interleukin-8 (IL-8), TNF $\alpha$, and monocyte chemoattractant protein-1 (MCP-1) associated with periodontitis can induce a rapid hepatic synthesis and secretion of plasmatic vascular proteins such as CRP and fibrinogen $[105,106]$. LPS produced by periodontal pathogens and released in the blood flow triggers an immunological response which, when associated with CRP and fibrinogen, may initiate atherosclerosis by acting on endothelial cells, lipid metabolism modulators, and enhancing oxidative stress $[107,108]$. LPS is transported and eliminated from the bloodstream by lipoproteins. It is associated with healthy people with HDL present, which helps in its neutralization in case of infection. When HDL levels decrease sharply, it mainly associates with VLDL (Very Low-Density Lipoproteins) [75,109]. LPS associated with VLDL crosses the barrier of endothelial cells to the intima, causing an alteration of lipid homeostasis. VLDL also potentiates the expression of TNF- $\alpha$ and MCP-1 by macrophages resulting in their activation [109]. This systemic response leads to an increase in the production of cytokines associated with an alteration in lipid metabolism. Patients with a lipoprotein profile predominantly consisting of small, dense LDL are three to seven times more likely to have a cardiovascular event than people with "normal" lipoprotein profiles. Studies have shown that periodontal infections could be correlated with this type of lipid profile [110].

In addition, dyslipidemia is more common in patients with periodontitis. It manifests itself by an increase in the levels of LDL and plasma triglycerides with, conversely, a decrease in HDL. A study has shown that patients with moderate periodontitis do not show quantitative but qualitative changes in LDL because there is an increase in VLDL as 
previously described [111]. In addition, the elevated levels of cholesterol and LDL noted in the bloodstream of patients with atherosclerosis have been positively correlated with the proliferation of Fusobacterium in the microbiota of their oral cavity [92].

\subsection{Chronic Obstructive Pulmonary Disease}

Although lungs have long been regarded as sterile, bacterial colonization begins soon after birth and is a dynamic process influenced by environmental and genetic factors. Bacteria from the upper respiratory tract and the environment reach the lower respiratory tract through breathing, mucociliary clearance, and microaspiration [112]. In healthy subjects, there are important similarities between oral and lung microbiota $[113,114]$, and a microbiome dominated by Streptococcus, Prevotella, Veillonella, Pseudomonas, Haemophilus, and Fusobacterium has been described in the respiratory tract [115]. While the mechanisms have yet to be understood, lung microbiota changes in chronic respiratory diseases are increasingly studied.

Chronic Obstructive Pulmonary Disease (COPD) is characterized by dyspnea, chronic cough, and sputum, resulting from chronic inflammation within the respiratory airways [116]. Lung microbiota evolves according to disease severity [117] and exacerbations, characterized by alveolar rupture, increased mucus production, and disease aggravation, which are mainly caused by microorganisms promoting inflammatory mediators production by inflammatory cells $[118,119]$. Studies showed that Haemophilus influenzae, Streptococcus pneumoniae (Sp), Pseudomonas aeruginosa $(\mathrm{Pa})$, and Moraxella catarrhalis are the main microorganisms involved in acute exacerbations of COPD (AECOPD) [118,120,121] and interestingly, a study showed the presence of $S p$ and $P a$ in subgingival plaque and $P g$ and $T d$ in the tracheal aspirates of patients suffering from acute exacerbation of COPD [122]. Several clinical studies showed that periodontitis is associated with an increased risk of developing COPD, independently of conventional risk factors (tobacco, age) [123,124]. Moreover, periodontal treatment is accompanied by a reduction of exacerbations and respiratory parameters $[125,126]$. Recent studies showed that $F n$ is able to induce proinflammatory cytokines IL- 6 and IL-8 production by respiratory epithelial cells in vitro and in vivo [127]. Moreover, $F n$ and $P a$, which coexist in the respiratory system of patients suffering from AECOPD, can collaborate to sustain bacterial growth in a co-culture model [128]. Simultaneous coinfection of human respiratory epithelial cell lines with $F n$ and $\mathrm{Pa}$ promotes cell invasion and induces IL-6, IL-8, and TNF- $\alpha$ in vitro [129].

Besides COPD, a recent study showed that periodontitis seems to be associated with increased risk of intensive care unit admission, need for assisted ventilation, and death of patients suffering from SARS-CoV-2 [130]. In vitro experiments suggest that the aspiration of periodontopathogen bacteria like $F n$ by patients with COVID-19 may aggravate lower respiratory tract inflammation [131].

\subsection{Rheumatoid Arthritis}

Rheumatoid arthritis (RA) is an auto-immune disease characterized by chronic inflammation of the joints. At the anatomopathological level, the synovial membrane, when inflamed, forms what is called a "pannus," which leads to the destruction of the joints. Its incidence is $0.5 \%$ to $1 \%$ and concerns mostly women between the ages of 40 and 60 [132]. In 50 to $70 \%$ of cases, patients produce autoantibodies against citrullinated peptides (ACPAs) and autoantibodies against IgG (RF, for rheumatoid factor) [133]. ACPAs are able to form immune complexes with citrulline-containing antigens that then link the RF, leading to important complement activation [134]. This immune activation is responsible for synovial membrane inflammation along with leucocyte infiltration into the synovial compartment of the joints [133]. This inflammation induces fibroblast activation, enhanced chondrocyte catabolism, and synovial osteoclastogenesis, leading ultimately to articular destruction [135]. Interestingly, circulating ACPAs can be detected long before RA diagnosis [136-138]. 
For several years, the role of periodontitis and its microbiota has been studied in the development of rheumatoid diseases such as RA. Indeed, studies have shown that patients with RA are more likely to develop chronic periodontitis compared to healthy people [139]. Other studies have shown that patients with RA have a significantly higher prevalence of moderate to severe periodontitis (62.5\%). In addition, patients with periodontal followup (therefore associated with periodontitis) have a higher prevalence of RA (4\%) than the general population (1\%) [132]. These two inflammatory pathologies develop under the influence of many common risk factors, whether genetic with the polymorphism of certain receptors, but also immune with increased production of interferon-gamma, B lymphocytes, and RANKL (Receptor Activator of Nuclear Factor-Kappa B Ligand) associated with activation of the inflammation system with a TH17 (lymphocyte T Helper cells expressing IL-17) profile [140]. The presence of bacteria in the synovia and an increased level of inflammatory mediators in the blood (CRP) were also common between these two pathologies [141]. Thus, there is a bidirectional link between periodontitis and RA: patients with periodontitis are more likely to suffer from RA, and conversely, patients with RA have a greater risk of periodontitis [138,142-144].

Chronic periodontitis is believed to be involved in the initiation and progression of RA mainly by two major biological pathways. First, the passage of bacteria and proinflammatory cytokine of periodontal origin in the bloodstream favoring the development of joint inflammation. In fact, many microorganisms are mentioned in these hypotheses, such as Mycoplasmas, viruses (Epstein Barr virus and Cytomegalovirus), and bacteria of the periodontal microbiota. The presence of bacterial DNA and peptidoglycans, constituents of their wall, in the joints of patients with RA has been demonstrated. Among periodontal bacteria, the most regularly detected are $P i$ and $P g$, as well as Bacteroides forsythus [145]. The prescription in these patients of antibiotic treatments against oral anaerobic bacteria leads to an improvement in the clinical signs of RA.

Secondly, the link between periodontitis and RA has been studied through the specific role of $P g$ due to its enzymes, the peptidyl-arginine-deiminases (PAD), which could carry out the citrullination (post-translational modification) of certain peptides [146]. The result is the production of antibodies that recognize the host's citrullinated peptides, which is indicative of clinical signs of RA. $P g$ is able to citrullinated bacterial and human proteins, leading to the formation of APCAs, and potentially contributing to the initiation of RA [147,148]. The positive assay of these ACPAs makes it possible to predict, with a specificity greater than $95 \%$, the early diagnosis of RA. Studies show that the level of anti- $P g$ antibodies is correlated with the level of ACPAs in patients with RA. The concentration of anti- $P g$ antibodies is increased in RA patients compared to healthy subjects and detectable several years before the appearance of RA symptoms [149]. More recently, a study showed that $A a$ is also able to release hyper-citrullinated proteins and that there is a strong association between the concentration of anti- $A a$ antibodies and the presence of ACPAs and RF in patients with RA [150].

While the effects of periodontal treatment are controversial, with conflicting results among studies, and well-conducted clinical trials are needed to conclude on this point [151-154] firmly, it seems that anti-inflammatory treatment for RA induces a reduction in gingival inflammation (IL-1 $\beta$ ) [155]. Interestingly, an in vivo study on mice showed that ACPAs serum concentration is reflected in the saliva. A human study observed alteration of oral microbiota in the pre-clinical stages of RA, suggesting that oral status could be an early marker of RA development [151,156]. There is, therefore, an interrelation between these two inflammatory pathologies with significant production of pro-inflammatory cytokines [152].

\subsection{Adverse Pregnancy Outcomes}

During pregnancy, physiological, immunological, and hormonal modifications occur in the mother, increasing her susceptibility to infections, including oral and periodontal diseases [153,154]. Also, changes in estrogen and progesterone levels affect the composition of the oral microbiota, which becomes compatible with the development of gingivitis and 
periodontitis [157,158]. Oral saliva of pregnant women that underwent 16S rRNA gene sequencing shows that the oral microbial diversity is relatively stable during pregnancy. However, compared to non-pregnant women, it makes a pathogenic shift during pregnancy associated with pregnancy gingivitis before reverting to a healthy microbiome during the post-partum period [159]. Also, oral dysbiosis, as described in periodontitis, can increase the risk of adverse pregnancy outcomes (APO), including preterm birth, preeclampsia, gestational diabetes, and low birthweight $[160,161]$. Furthermore, maternal periodontal conditions seem to be associated with stillbirth and perinatal death [162,163]. Three biological mechanisms supporting this relationship between periodontal diseases and APO have been proposed: one through systemic dissemination of periodontal pathogens that could cross the placenta into the amniotic fluid and fetal circulation, the other through inflammatory mediators such as IL-6, IL- 8 , and TNF- $\alpha$ produced during periodontal inflammation that could, by entering the systemic circulation, induce an acute inflammatory response affecting the fetus and placenta, and finally, the possibility of oral microbiological transmission to the vaginal microbiome resulting from sexual practice $[9,164,165]$. Also, the placenta harbors a unique microbiome structured by the history of antenatal infections and shares similarities with the oral microbiome [166]. Recent studies have shown that both placental and oral microbiomes may play a role in periodontitis-associated APO [167]. $\mathrm{Pg}$ and $\mathrm{Fn}$ Gram-negative anaerobes commonly found in periodontitis have been shown to be able to translocate to the fetal-placental unit $[168,169]$ and are associated with APO such as preeclampsia, early-onset neonatal sepsis, and stillbirth $[167,170]$.

Finally, concerning the transmission of the maternal microbiome to the child, recent research on families with adopted and biological children shows that the composition of the microbiome seems to be shaped more by the host and contact with the local environment than by genetics and direct transfer of this microbiome through pregnancy outcomes and especially delivery modes (C-section or vaginal delivery) [4]. Babies fed only on breast milk have a lower diversity with a decreased relative abundance of Veillonella, Prevotella, Granulicatella, and Porphyromonas than those fed only on formula, but these differences do not persist over time. Also, at two months, the salivary microbiome of infants delivered by C-section is significantly more diverse than those delivered vaginally, but again these differences seem to disappear at 12 months [171]. The salivary microbiome is dynamic during the first two years of life, and age-related factors seem to be the strongest determinants. Colonization by species such as Candida albicans is a good example of these age-related changes in exposure [171].

\subsection{Inflammatory Bowel Diseases}

Chronic inflammatory bowel diseases (IBD) mainly include Crohn's disease and ulcerative colitis. These pathologies are characterized by chronic intestinal inflammation evolving into a variable course of flare-ups and remissions. Although the etiology is still imperfectly known today, the main hypothesis is an inadequate intestinal immune response to bacteria in the commensal flora, probably triggered by environmental factors associated with genetic predispositions. Extra-digestive manifestations at the musculo-articular, cutaneous, oral, and ophthalmological levels are the most frequent and often progress in parallel to digestive disease outbreaks $[172,173]$. The oral cavity is a preferential site for extra-digestive manifestations: $50 \%$ of IBD patients develop oral lesions with a wide variety of clinical forms [174]. They may be specific to intestinal pathology (inaugural, at the same time, or after the appearance of gastrointestinal symptoms), or they may be reactive, i.e., the consequence of drug treatments and nutritional deficiencies due to malabsorption and malnutrition (so-called non-specific lesions) $[175,176]$. They may also be an early sign of therapeutic escape or disease relapse. People suffering from IBD are characterized by dysbiotic oral and gut microbiota with a decrease in bacterial diversity, a decrease in the abundance of Firmicutes phylum, and an increase in the abundance of Proteobacteria and Bacteroidetes phylum [102,177-179]. Recent studies showed that, compared to healthy people, these people also presented an oral dysbiosis and that periodontitis was significantly 
associated with IBD $[180,181]$. However, the exact nature of oral dysbiosis remains unclear and differs between studies. Some authors observed an increase in Eikenella corrodens, Prevotella genus, Veillonella genus, and a decrease in Streptococcus genus, Haemophilus genus, Neisseria, and Gemella families in IBD patients compared to healthy subjects $[182,183]$. However, others observed an increase in Campylobacter genus, Streptoccocaceace, Enterobacteriaceae, and Veillonellaceae families and a decrease in Porphyromonadaceae and Neisseriaceae families [184-186]. Furthermore, the oral microbiota of Crohn's disease patients was associated with a decrease in Neisseria, Haemophilus, Fusobacterium, and Porphyromonas genera compared to patients in remission [187]. In addition, an increase in the number of oral bacteria in the gut microbiota has been observed in IBD patients: Aggregatibacter, Campylobacter, Enterobacteria, Fusobacterium, Gemella, Neisseria, Veillonella, Peptostreptococcus, and Streptococcus [188-190]. Therefore, it can be assumed that the oral microbiota, capable of colonizing the gastrointestinal tract, may act as a pathogen reservoir and thus play a role in the pathogenesis and aggravation of IBD [188,191]. There are two possible mechanisms for the translocation of oral bacteria into the gut: the haematogenous route and the enteral route. Oral dysbiosis (characterized by an increase in Gram-negative bacteria) can lead to translocation of these bacteria and their virulence factors into the bloodstream. This leads to an increased immune and inflammatory response at the systemic level [9]. The function of the intestinal barrier may also be impaired. Studies in mice have shown that oral administration of $P g$ increased intestinal barrier permeability through down-regulation of tight junction proteins, resulting in significant alteration of the gut microbiome. In addition, mice inoculated with $P g$ exhibited intestinal and systemic inflammation caused by $P g$-derived endotoxins, such as LPS [192,193]. Another possible route of dissemination of oral bacteria is enteral dissemination. IBD patients have chronic intestinal inflammation with an altered intestinal barrier that leads to increased colonization of oral bacteria at the intestinal level $[188,189]$. The impact of these oral pathogens in the gut can lead to worsening of chronic gut inflammation. Inoculation of the oral microbiome of IBD children into germ-free mice resulted in enrichment of Fusobacterium, Veillonella and Klebsiella spp. in the gut. Ectopic colonization of these bacteria and in particular Klebsiella spp. caused potent T helper 1 (TH1) cell differentiation and inflammation in the gut [194]. Mechanisms of ectopic colonization of the gut by oral bacteria and their role in pathogenesis of IBD still need to be clarified. A better understanding of the oral microbiota in IBD could initiate the development of new diagnostic and therapeutic tools and strategies to target oral bacteria in the management of IBD.

\subsection{Alzheimer's Disease}

Alzheimer's disease (AD) is a neurodegenerative disease. It causes progressive and irreversible loss of memory (amnesia), executive function, language (agnosia), and Spatiotemporal orientation disorders leading to dementia and death. It is the most common cause of dementia, with a prevalence of approximately $60-80 \%$ worldwide $[195,196]$. AD is characterized, on the one hand, by the formation of amyloid plaque (also called senile plaque) caused by an extracellular accumulation of the nerve cell-toxic beta-amyloid peptide. On the other hand, neurofibrillary degeneration is related to the accumulation of phosphorylated tubulin-associated unit (TAU) proteins [197]. Inflammation plays an important role in the development and progression of AD. Indeed, there is a close link between beta-amyloid proteins, oxidative stress, and neuroinflammation in the brain, which leads to the loss of neurons and disease progression [198]. The most commonly cited risk factors are genetic and environmental [199]. In recent years, numerous studies have suggested the involvement of oral microbiota in AD [200-202]. Patients with AD present a dysbiotic oral microbiota with a decrease of bacterial diversity and an increase of prevalence of the Moraxella, Leptotrichia, and Sphaerochaeta genera [203]. Moreover, serum antibodies to seven oral bacteria ( $\mathrm{Aa}$, Campylobacter rectus, $\mathrm{Fn}, \mathrm{Pg}, \mathrm{Pi}, \mathrm{Tf}$, and $\mathrm{Td}$ ) have been found at a higher level in patients with AD, compared with controls [204]. Correlation between the presence or absence of periodontitis and AD has been reported [205,206]. Tooth loss is 
positively associated with an increased risk of dementia in adults [207]. Two mechanisms may contribute to the progression of $\mathrm{AD}$ via the dysbiotic oral microbiota. First, the interaction between oral bacteria or meta factors (e.g., LPS) and the host response leads to a significant production of inflammatory molecules at the systemic level via the TLR-4/NF$\kappa B$ signaling pathway $[208,209]$. Systemic inflammation and pro-inflammatory mediators such as CRP, TNF- $\alpha$, IL-6, and IL-1, are able to activate microglia, which induce increased production of pro-inflammatory molecules and exacerbate neuroinflammation leading to neurodegeneration [210]. The other mechanism by which oral bacteria may contribute to brain inflammation is through bacterial translocation. Not only pro-inflammatory cytokines but also Gram-negative oral bacteria and their virulence factors (LPS) can enter the brain via the blood-brain barrier. LPS from $P g$ and $T d$ have been found in post-mortem human brains with AD [211]. Studies on mice have shown the presence of $P g$ in the brain after oral injection. Exposure to $P g$ induced Alzheimer's disease-like phenotypes in mice with neurodegeneration, amyloid accumulation, impaired cognitive function and reduced learning and memory [210-213]. Finally, a person with dementia or AD has difficulty maintaining good oral hygiene or regular follow-ups with the dentist, which increases the risk of poor oral health and oral dysbiosis. Also, a recent study exploring the relationships between $\mathrm{AD}$ and periodontal treatment, showed that periodontal treatment had a favorable effect on AD-related brain atrophy explored by magnetic resonance imaging [214].

\subsection{Autism Spectrum Disorders}

Autism spectrum disorders (ASD) are complex neurodevelopmental disorders that manifest themselves in the first two years of life. They are characterized by persistent deficits in attention, language, and social interaction, often accompanied by restricted interests and repetitive behavior [215]. The prevalence of ASD has been steadily increasing over the past decades. Currently, $1 \%$ of the general population is affected by ASD [216]. The causes of autism are still poorly defined. The involvement of several risk factors has been highlighted: genetic, environmental, neuro-pathological, inflammatory, and immunological. Also, maternal prenatal infection and high levels of pro-inflammatory cytokines increase the risk of ASD in children. Concerning microbiota, studies have focused mainly on the relationship between dysbiosis of the intestinal microbiota and ASD, highlighting the microbiota-gut-brain axis in the animal model. However, an increasing number of studies are looking into the role played by the oral cavity and its microbiota. Children with ASD do not have specific oral characteristics related to their pathology, but limited communication, self-neglect, self-mutilation, and eating habit (soft and sweet food) disorders have consequences on their oral health. They have poorer oral hygiene, a higher prevalence of caries, bruxism, and erosions due to frequent regurgitations [217-219]. Pain hypersensitivity and communication difficulties lead to delayed oral health care. A recent study showed a difference in the composition of the oral microbiota in ASD patients compared to controls. Patients with ASD showed a decrease in bacterial diversity, an increase in the proportion of pathogenic bacteria such as Haemophilus and Streptococcus, and a decrease in the proportion of commensal bacteria such as Alloprevotella, Prevotella, Selenomonas, Actinomyces, Porphyromonas, and Fusobacterium [220]. Furthermore, a similar change in the gut microbiota in children with ASD has also been observed, suggesting a potential interaction of the oral microbiota on the gut microbiota [220-222]. To date, the direct relationship between ASD and oral microbiota has not been clearly established. However, saliva can be used as a biomarker to help diagnose ASD and allow early management. Recently, the measurement of salivary poly-omic RNA has been described as a new approach to identify children with ASD [223] accurately. Finally, dysbiosis of the microbiota may modulate social behavior, and conversely, restoration of a healthier microbiota may improve ASD symptoms [224,225]. Wang et al. reported that oral probiotics could reduce ASD-like behaviors in offspring induced by maternal immune activation [226]. 


\subsection{Oral Mucosal Disease}

Oral mucosal disease (OMD) is a series of disorders or conditions affecting the oral soft tissues and mucosa. OMD mainly includes oral infectious diseases such as oral candidiasis, oral lichen planus (OLP) or oral mucosal patches striae diseases, ulcerative lesions such as recurrent aphthous ulcers (RAU), oral premalignant lesions like oral leukoplakia (OLK), and oral cancers, mainly oral squamous cell carcinoma (OSCC) [227]. OMDs share multiple risk factors, including genetic predisposition, immunological disturbances, viral and bacterial infections, food allergies, and nutritional deficiencies, and also hormonal imbalance, mechanical repetitive injuries, and stress. Even though their etiopathogenesis is not yet fully understood, it is well admitted that these different risk factors have the ability to disrupt the diversity and composition of the commensal oral microbiota leading to oral dysbiosis [228].

\subsubsection{Oral Microbiota and Oral Lichen Planus}

Oral lichen planus (OLP) is a common chronic T-cell-mediated inflammatory oral mucosal disease that occurs in approximately $0.5-2 \%$ of the general adult population, with a higher prevalence in women than in men [229]. OLP affects the buccal mucosa, but also the gingiva, tongue, and lips, and in some cases, skin, nails, eyes, and urogenital mucosa. There are essentially two forms of OLP lesions: reticular or non-erosive and erosive. The erosive and non-erosive but atrophic forms of OLP may cause soreness and discomfort and have also been reported as being at risk of malignant transformation in $1-2 \%$ of cases [223]. Recent studies on the composition of the oral microbiome focusing particularly on the mycobiome in salivary samples showed that OLP patients (both erosive and reticular forms) had, overall, lower biodiversity of their oral fungal community but an increase in the abundance and frequencies of the genera Candida and Aspergillus [230]. Interestingly, however, the patients' bacteriome was significantly more diverse than that of healthy subjects. Also, Candida was positively correlated with several anaerobic, periodontopathogen bacterial genera such as Treponema, Bacteroides, Aggregatibacter, Captnocytophaga, and Veillonella [230]. Candida, by its high level of $\mathrm{O}_{2}$ consumption permitting the formation of an anaerobic micro niche for these strictly anaerobic bacterial species.

\subsubsection{Oral Microbiota and Recurrent Aphthous Ulcers}

Recurrent aphthous ulcers (RAU) or recurrent aphthous stomatitis (RAS), characterized by shallow round painful ulcers, are the most common form of oral ulcerative diseases that affect as much as $5-20 \%$ of the population [231]. Using new tools to investigate the oral microbiome, such as throughput sequencing and pyrosequencing, has led to the identification of potential bacterial candidates responsible for RAU. The increase in E. Coli and Alloprevotella associated with a decrease of Streptococcus seems to be responsible for RAU [232]. When comparing the oral microbiota of healthy and RAU subjects, the salivary microbiota of RAU subjects tended to contain decreased Firmicutes and increased Proteobacteria. Also, a decrease in Streptococcus salivarius and an increase in Acinetobacter johnsonii seem to be associated with RAU risk [233]. Finally, when comparing erosive OLP and RAU lesions, studies found that their microbiome was significantly different. The microbiome changes may thus be more related to the diseases themselves rather than to the oral lesions observed clinically. For example, Streptococcus and Sphingomonas were two of the most abundant bacterial species found in the saliva of OLP patients but were also two of the less abundant species found in the saliva of RAU patients [234]. Taken together, these findings could lead to the development of future diagnostic tools and offer new insight on host immunologic responses and possible cause-effect relationships of these disorders.

\subsubsection{Oral Microbiota and Oral Leukoplakia (OLK) and Oral Squamous Cell Carcinoma (OSCC)}

Oral leukoplakia (OLK) is defined as a predominantly white lesion of the oral mucosa that cannot be wiped off the mucosa or ascribed to any specific disease process. OLK is often considered a premalignant OMD [228]. Oral squamous cell carcinoma (OSCC) 
represents the most common cancer of the oral cavity and comprises $80-90 \%$ of head and neck cancers with a 50\% survival rate at 5 years [235]. The role of specific microbiotas on the development of cancers can be explained through different mechanisms, especially the production of toxins, loss of hormonal homeostasis, and immune tolerance, but also induction of chronic inflammatory signals and carcinogenic metabolites [236]. Several studies on the oral microbiome have been carried out to identify potential microbiota changes and bacteria candidates specific to OLK and OSCC $[237,238]$. Also, there seems to be a shift in the oral microbiome profile associated with disease progression from OLK to OSCC and during cancer progression from stage 1 to stage $4[238,239]$. Such as in OLP, colonization with Candida albicans is common. Studies have shown that, even though bacteria colonization patterns are highly variable, increased abundance of Fusobacteria and reduced levels of Firmicutes are found in OLK [240]. When comparing the salivary microbiome of OLK patients to OSCC subjects, researchers have shown that OSCC subjects have a higher abundance of the phylum Bacteroidetes and Solobacterium genus compared to the OLK group, whereas the Streptococcus genus was significantly lower in the OSCC group compared to OLK [241]. This microbiome shift could be a novel precursor marker of malignant transformation of a precancerous lesion [227]. Despite recent data and research progress in the field liking microbiome changes and OMDs, several challenges remain in order to confirm this correlation. Also, confirmation will be essential in order to the make the oral microbiome the target of future diagnostic tools and preventive treatments for OMDs modulation therapies.

\section{Oral Cavity as a Reflection, Target, and Actor of Our General Health}

As summarized in Figure 2, the literature shows increased evidence on the links between the oral cavity, its dysbiotic microbiota, and systemic diseases $[8,157,242]$. Oral diseases are now considered to be the consequence of a deleterious change in the balance of the oral microbiota making oral microbiota identification and management a major research axis of great interest for practitioners (Figure 3).

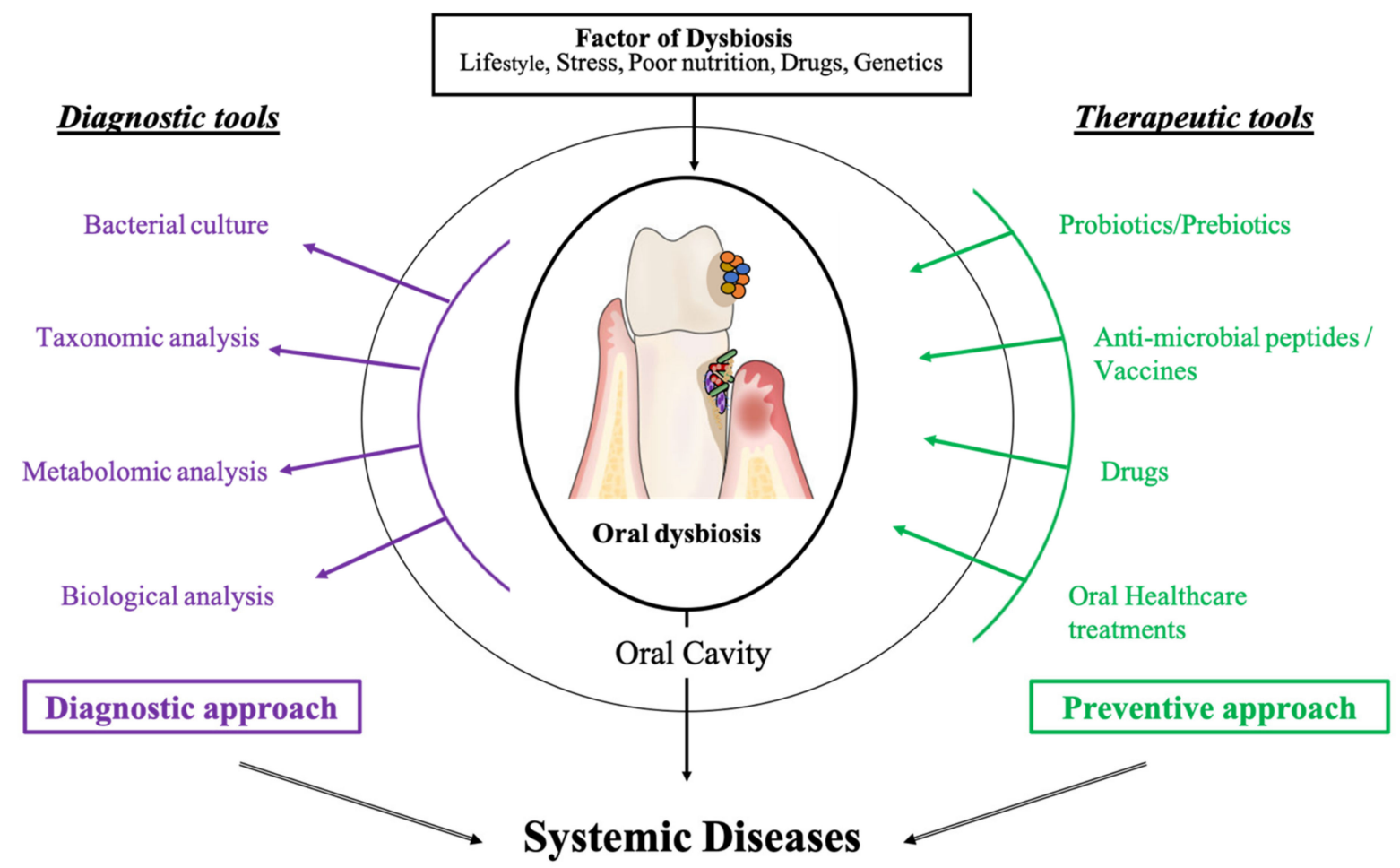

Figure 3. The oral microbiota is a biomarker, diagnostic tool, and target for systemic disease diagnosis and treatment. 


\subsection{Saliva as a Diagnostic Tool}

Because it is easily accessible in a non-invasive and inexpensive way, saliva is becoming the new fluid of major interest in the detection of systemic parameters [243]. Salivary biomarkers allow the implementation of novel strategies to help diagnose, limit the prevalence of systemic diseases, and offer new therapeutic tools. The best example came in the past 18 months, with the SARS-CoV-2 infection. Not only is the oral cavity the siege site of the viruses side effects (infection, loss of taste, mucosal damage) and a probably underestimated site for SARS-CoV-2 infection [244], it also offers, with saliva analysis, a quick, reliable, and simple method for collecting samples compared to the nasopharyngeal test [245]. Several kits are already commercialized and used chair side to detect caries (CRT bacteria $^{\circledR}$ ), periodontal diseases, or IL-6 polymorphism (MyPerioPath ${ }^{\circledR}$, My PerioID ${ }^{\circledR}$ ) or to determine the risk of developing OSCC (OraRisk ${ }^{\circledR}$ HPV test) [246]. Furthermore, in the field of cancer, the development of techniques such as liquid biopsies and saliva liquid biopsies are being investigated with promising results, especially in lung cancer [247-249]. Because saliva is easier to collect, store, and analyze, research in salivaomics will have an important impact in the future to diagnose systemic diseases and potentially monitor disease relapse or aggravation $[249,250]$.

Further technological innovation could reside in the creation of biosensors incorporated in the teeth and measuring the levels of oral biomarkers or quantify enzymes or bacteria present in the oral cavity. These biosensors may be the next approach to monitor an individual's metabolic status continuously. Mannoor et al. proposed a first version of a "connected tooth" [251]. These authors reported the "grafting" onto a tooth of a graphene "nano sensor" of antimicrobial peptides (antimicrobial peptides or AMP) existing in nature to detect certain species such as Escherichia coli, Helicobacter pylori, or Staphylococcus aureus. They showed that it was possible to detect the binding of a single bacterium on a sensor, confirming the idea that biosensors incorporated in the teeth could possibly be used to monitor disease status constantly. This would support David Wong's proposition that "oral fluid (saliva), the mirror of the body, is a perfect medium to explore for health and disease surveillance" [252].

\subsection{Novel Therapeutic Strategies}

At the dawn of new, less invasive medicine, one wonders about the benefit of broadspectrum eradication of oral bacteria and the increase in microbial resistance due to multiple antiseptic and antibiotic treatments [253-256]. The problem for healthcare practitioners is to offer innovative therapies to resolve the prevalence and co-morbidity of oral and systemic diseases. The search for and development of new therapeutic approaches should, however, not undermine the use of existing therapies such as oral health education, restorative dentistry, and non-surgical periodontal therapies in controlling oral dysbiosis and restoring a healthy environment $[257,258]$.

Unfortunately, such "classic" treatments are often insufficient in maintaining oral eubiosis [259]. Thus, new preventive strategies using pre/probiotics are emerging [260]. Numerous studies on the oral microbiota allowed scientists and mathematicians to generate a large database that can lead to the identification of new probiotics from oral microbiota in metabolic regulation. Already, specific probiotics such as Bifidobacterium pseudocatenulatum and Bifidobacterium catenulatum are used to treat liver damage by attenuating D-galactosamine [261]. Also, in mice, treatment with the probiotic Bifidobacterium pseudocatenulatum reduces obesity and inflammation by improving the epithelial barrier of the oral cavity $[262,263]$. In the oral cavity, guided periodontal pocket recolonization associated with periodontal non-surgical treatment reduced local inflammation and improved long-term clinical outcomes [264]. For example, nitrate used as a prebiotic or a symbiotic with nitrate-reducing probiotics could be promising in preventing oral disease and improving systemic conditions such as hypertension and diabetes, as shown in an in vitro study [265]. 
Another approach relies on host modulation therapy in order to control and reduce local inflammation, thus reducing systemic inflammation $[266,267]$. AMPs can affect the homeostasis of the oral cavity through the broad or selective killing of bacteria, but also, due to their immunomodulatory properties, they can influence both the innate and adaptive immune response [268,269]. The most studied AMPs are Leucine leucine-37 (LL-37), $\alpha$-, and $\beta$-defensins. A recent systematic review on the subject reveals that, in saliva, some AMPs such as LL-37, HNP1-3 (Human Neutrophil Peptide 1-3), substance $\mathrm{P}$, adrenomedullin, azurocidin, and some others were increased in periodontal disease, while others like calcitonin gene-related protein or neuropeptide $Y$ were decreased [270]. They could thus be used either as novel disease markers or designed to target specific oral bacteria. Next to AMPs, other fields are investigated, and recently, an oxygen transporter derived from the marine lugworm Arenicola marina, HEMARINA-M101 (M101), was tested. M101's anti-inflammatory and anti-infectious potential, based on its anti-oxidative and tissue oxidation properties, have been tested in vitro on biofilm cultures containing $P g$ and in vivo in a $P g$-induced subcutaneous calvarial abscess in a mouse model [271]. The results showed that M101 significantly reduced the release of pro-inflammatory cytokines and also had an anti-bacterial effect on $P g$, confirming its pro-healing properties and making it a potential therapeutic agent in periodontal wound healing and regeneration [271].

Also, oral and chronic systemic diseases share nutrition as a risk factor. Even if the role of micronutrients and vitamins remains to date still unclear, any change in oral health should be considered as a warning sign in the prevention of the development of systemic diseases [272]. For example, in in-vivo animal models, Resolvin E1, an endogenous anti-inflammatory lipid mediator derived from Omega-3 eicosapentaenoic acid, seems to suppress bone loss and restore systemic levels of IL-1 $\beta$ and CRP, also attenuating the inflammatory signal leading to periodontal destruction with no unwanted side-effects $[273,274]$. Another example is the level of vitamin $\mathrm{D}$ and its role in periodontal disease and metabolic disorders [275-278]. The relationship between vitamin D deficiency and insulin resistance could be explained by inflammation, as vitamin D deficiency is associated with increased inflammatory markers, initial insulin resistance, and subsequent onset of diabetes caused by the death of $\beta$ cells. In fact, we now know that chronic periodontitis [279] is associated with a low level of vitamin D and, more precisely, with a low serum level of $1.25(\mathrm{OH})$ 2D. This type of link corresponds to the associations previously reported between vitamin D and other inflammatory diseases [280,281]. Epidemiological studies have shown an association between a low serum concentration of 25-hydroxyvitamin D3 $(25(\mathrm{OH})$ D3) and an increased risk of metabolic syndrome and Type 2 diabetes, which may be explained in part by an increase in blood pressure [278]. Importantly, genetic polymorphisms in genes linked to vitamin D can predispose to impaired glycemic control and T2D [282].

Finally, identifying new bacteria candidates using novel techniques such as nextgeneration sequencing and new delivery systems designed specifically for targeting oral bacteria (i.e., caries or periodontal disease-associated oral dysbiosis) could lead to the development of vaccines in the near future [283-285].

\section{Conclusions}

Oral microbiota is a complex organism acquired from birth, influenced by environmental, genetic, and behavioral factors. It interacts with the host's other microbiotas and is important in health and disease. Diagnosing, controlling, and treating oral dysbiosis can have an impact on systemic diseases and patients' oral and general wellbeing [286]. It also has an impact on society from a socio-economic point of view [287-289].

Data from the literature concerns many medical specialties such as cardiology, angiology, dermatology, and endocrinology, and even if future studies are needed in order to fully understand the link and assess the impact of oral health on general health and vice versa, oral specialists should be aware of its existence and work together with other medical specialists to better serve their patients' needs and improve their quality of life. 
Author Contributions: C.T., M.M., A.V., V.B.-B. and S.L.-D.: writing-review and editing. C.T., M.M., A.V., T.C., P.L., R.B., M.K., V.B.-B. and S.L.-D.: critically revised manuscript. All authors have read and agreed to the published version of the manuscript.

Funding: This research received no external funding.

Institutional Review Board Statement: Not applicable.

Informed Consent Statement: Not applicable.

Data Availability Statement: Not applicable.

Conflicts of Interest: The authors declare no conflict of interest.

\section{References}

1. Hug, L.A.; Baker, B.; Anantharaman, K.; Brown, C.T.; Probst, A.; Castelle, C.; Butterfield, C.N.; Hernsdorf, A.W.; Amano, Y.; Ise, K.; et al. A new view of the tree of life. Nat. Microbiol. 2016, 1, 16048. [CrossRef] [PubMed]

2. Baker, J.; Bor, B.; Agnello, M.; Shi, W.; He, X. Ecology of the Oral Microbiome: Beyond Bacteria. Trends Microbiol. 2017, 25, 362-374. [CrossRef] [PubMed]

3. Zhang, Y.; Wang, X.; Li, H.; Ni, C.; Du, Z.; Yan, F. Human oral microbiota and its modulation for oral health. Biomed. Pharmacother. 2018, 99, 883-893. [CrossRef] [PubMed]

4. Mukherjee, C.; Moyer, C.O.; Steinkamp, H.M.; Hashmi, S.B.; Beall, C.J.; Guo, X.; Ni, A.; Leys, E.J.; Griffen, A.L. Acquisition of oral microbiota is driven by environment, not host genetics. Microbiome 2021, 9, 1-13. [CrossRef]

5. Gomez, A.; Nelson, K.E. The Oral Microbiome of Children: Development, Disease, and Implications Beyond Oral Health. Microb. Ecol. 2017, 73, 492-503. [CrossRef]

6. Weyrich, L.S. The evolutionary history of the human oral microbiota and its implications for modern health. Periodontology 2000 2021, 85, 90-100. [CrossRef]

7. Lamont, R.J.; Koo, H.; Hajishengallis, G. The oral microbiota: Dynamic communities and host interactions. Nat. Rev. Genet. 2018, 16, 745-759. [CrossRef]

8. Graves, D.; Corrêa, J.; Silva, T. The Oral Microbiota Is Modified by Systemic Diseases. J. Dent. Res. 2018, 98, 148-156. [CrossRef] [PubMed]

9. Hajishengallis, G. Periodontitis: From microbial immune subversion to systemic inflammation. Nat. Rev. Immunol. 2015, 15, 30-44. [CrossRef]

10. Gao, L.; Xu, T.; Huang, G.; Jiang, S.; Gu, Y.; Chen, F. Oral microbiomes: More and more importance in oral cavity and whole body. Protein Cell 2018, 9, 488-500. [CrossRef] [PubMed]

11. Verma, D.; Garg, P.K.; Dubey, A.K. Insights into the human oral microbiome. Arch. Microbiol. 2018, 200, 525-540. [CrossRef]

12. Tuominen, H.; Collado, M.C.; Rautava, J.; Syrjänen, S.; Rautava, S. Composition and maternal origin of the neonatal oral cavity microbiota. J. Oral Microbiol. 2019, 11, 1663084. [CrossRef] [PubMed]

13. Kaan, A.M.; Kahharova, D.; Zaura, E. Acquisition and establishment of the oral microbiota. Periodontology 2000 2021, 86, $123-141$. [CrossRef]

14. Dewhirst, F.E.; Chen, T.; Izard, J.; Paster, B.J.; Tanner, A.C.R.; Yu, W.-H.; Lakshmanan, A.; Wade, W.G. The Human Oral Microbiome. J. Bacteriol. 2010, 192, 5002-5017. [CrossRef]

15. Aas, J.A.; Paster, B.J.; Stokes, L.N.; Olsen, I.; Dewhirst, F.E. Defining the Normal Bacterial Flora of the Oral Cavity. J. Clin. Microbiol. 2005, 43, 5721-5732. [CrossRef]

16. Xu, X.; He, J.; Xue, J.; Wang, Y.; Li, K.; Zhang, K.; Guo, Q.; Liu, X.; Zhou, Y.; Cheng, L.; et al. Oral cavity contains distinct niches with dynamic microbial communities. Environ. Microbiol. 2014, 17, 699-710. [CrossRef] [PubMed]

17. Marsh, P.D.; Do, T.; Beighton, D.; Devine, D.A. Influence of saliva on the oral microbiota. Periodontology 2000 2016, 70, 80-92. [CrossRef] [PubMed]

18. Pedersen, A.M.L.; Belstrøm, D. The role of natural salivary defences in maintaining a healthy oral microbiota. J. Dent. 2019, 80 (Suppl. S1), S3-S12. [CrossRef] [PubMed]

19. Hojo, K.; Nagaoka, S.; Ohshima, T.; Maeda, N. Bacterial Interactions in Dental Biofilm Development. J. Dent. Res. 2009, 88, 982-990. [CrossRef]

20. Li, J.; Helmerhorst, E.; Leone, C.; Troxler, R.; Yaskell, T.; Haffajee, A.; Socransky, S.; Oppenheim, F. Identification of early microbial colonizers in human dental biofilm. J. Appl. Microbiol. 2004, 97, 1311-1318. [CrossRef]

21. Marsh, P.D.; Zaura, E. Dental biofilm: Ecological interactions in health and disease. J. Clin. Periodontol. 2017, 44 (Suppl. S18), S12-S22. [CrossRef]

22. Takahashi, N.; Nyvad, B. The Role of Bacteria in the Caries Process: Ecological perspectives. J. Dent. Res. 2010, 90, 294-303. [CrossRef]

23. Hajishengallis, E.; Parsaei, Y.; Klein, M.; Koo, H. Advances in the microbial etiology and pathogenesis of early childhood caries. Mol. Oral Microbiol. 2017, 32, 24-34. [CrossRef]

24. Mira, A.; Simon-Soro, A.; Curtis, M.A. Role of microbial communities in the pathogenesis of periodontal diseases and caries. J. Clin. Periodontol. 2017, 44 (Suppl. S18), S23-S38. [CrossRef] 
25. Tanner, A.; Kressirer, C.; Rothmiller, S.; Johansson, I.; Chalmers, N. The Caries Microbiome: Implications for Reversing Dysbiosis. Adv. Dent. Res. 2018, 29, 78-85. [CrossRef] [PubMed]

26. Socransky, S.S.; Haffajee, A.D.; Cugini, M.A.; Smith, C.; Kent, R.L., Jr. Microbial complexes in subgingival plaque. J. Clin. Periodontol. 1998, 25, 134-144. [CrossRef]

27. Armitage, G.C.; Dickinson, W.R.; Jenderseck, R.S.; Levine, S.M.; Chambers, D.W. Relationship Between the Percentage of Subgingival Spirochetes and the Severity of Periodontal Disease. J. Periodontol. 1982, 53, 550-556. [CrossRef] [PubMed]

28. Curtis, M.A.; Diaz, P.I.; Van Dyke, T.E. The role of the microbiota in periodontal disease. Periodontology 2000 2020, 83, 14-25. [CrossRef] [PubMed]

29. Diaz, P.I.; Hoare, A.; Hong, B.-Y. Subgingival Microbiome Shifts and Community Dynamics in Periodontal Diseases. J. Calif. Dent. Assoc. 2016, 44, 421-435. [PubMed]

30. Abusleme, L.; Dupuy, A.K.; Dutzan, N.; Silva, N.; Burleson, J.A.; Strausbaugh, L.D.; Gamonal, J.; Diaz, P.I. The subgingival microbiome in health and periodontitis and its relationship with community biomass and inflammation. ISME J. 2013, 7, 1016-1025. [CrossRef] [PubMed]

31. Scannapieco, F.A.; Dongari-Bagtzoglou, A. Dysbiosis revisited. Understanding the role of the oral microbiome in the pathogenesis of gingivitis and periodontitis: A critical assessment. J. Periodontol. 2021. [CrossRef]

32. Loh, G.; Blaut, M. Role of commensal gut bacteria in inflammatory bowel diseases. Gut Microbes 2012, 3, 544-555. [CrossRef] [PubMed]

33. Gross, E.L.; Beall, C.; Kutsch, S.R.; Firestone, N.D.; Leys, E.J.; Griffen, A.L. Beyond Streptococcus mutans: Dental Caries Onset Linked to Multiple Species by $16 \mathrm{~S}$ rRNA Community Analysis. PLoS ONE 2012, 7, e47722. [CrossRef]

34. Abusleme, L.; Hoare, A.; Hong, B.; Diaz, P.I. Microbial signatures of health, gingivitis, and periodontitis. Periodontology 2000 2021, 86, 57-78. [CrossRef] [PubMed]

35. Hettne, K.M.; Weeber, M.; Laine, M.L.; Cate, H.T.; Boyer, S.; Kors, J.A.; Loos, B.G. Automatic mining of the literature to generate new hypotheses for the possible link between periodontitis and atherosclerosis: Lipopolysaccharide as a case study. J. Clin. Periodontol. 2007, 34, 1016-1024. [CrossRef] [PubMed]

36. Zelkha, S.A.; Freilich, R.W.; Amar, S. Periodontal innate immune mechanisms relevant to atherosclerosis and obesity. Periodontology 2000 2010, 54, 207-221. [CrossRef]

37. Lamster, I.B.; Pagan, M. Periodontal disease and the metabolic syndrome. Int. Dent. J. 2017, 67, 67-77. [CrossRef] [PubMed]

38. Nibali, L.; Tatarakis, N.; Needleman, I.; Tu, Y.-K.; D'Aiuto, F.; Rizzo, M.; Donos, N. Association Between Metabolic Syndrome and Periodontitis: A Systematic Review and Meta-analysis. J. Clin. Endocrinol. Metab. 2013, 98, 913-920. [CrossRef] [PubMed]

39. Morita, T.; Yamazaki, Y.; Mita, A.; Takada, K.; Seto, M.; Nishinoue, N.; Sasaki, Y.; Motohashi, M.; Maeno, M. A Cohort Study on the Association Between Periodontal Disease and the Development of Metabolic Syndrome. J. Periodontol. 2010, 81, 512-519. [CrossRef] [PubMed]

40. Fan, Y.; Pedersen, O. Gut microbiota in human metabolic health and disease. Nat. Rev. Genet. 2021, 19, 55-71. [CrossRef]

41. Pascale, A.; Marchesi, N.; Marelli, C.; Coppola, A.; Luzi, L.; Govoni, S.; Giustina, A.; Gazzaruso, C. Microbiota and metabolic diseases. Endocrine 2018, 61, 357-371. [CrossRef]

42. Nitta, H.; Katagiri, S.; Nagasawa, T.; Izumi, Y.; Ishikawa, I.; Izumiyama, H.; Uchimura, I.; Kanazawa, M.; Chiba, H.; Matsuo, A.; et al. The number of microvascular complications is associated with an increased risk for severity of periodontitis in type 2 diabetes patients: Results of a multicenter hospital-based cross-sectional study. J. Diabetes Investig. 2017, 8, 677-686. [CrossRef]

43. Arneth, B.; Arneth, R.; Shams, M. Metabolomics of Type 1 and Type 2 Diabetes. Int. J. Mol. Sci. 2019, 20, 2467. [CrossRef] [PubMed]

44. Graves, D.T.; Ding, Z.; Yang, Y. The impact of diabetes on periodontal diseases. Periodontology 2000 2020, 82, 214-224. [CrossRef]

45. Kolb, H.; Martin, S. Environmental/lifestyle factors in the pathogenesis and prevention of type 2 diabetes. BMC Med. 2017, 15, 1-11. [CrossRef] [PubMed]

46. Sharma, S.; Tripathi, P. Gut microbiome and type 2 diabetes: Where we are and where to go? J. Nutr. Biochem. 2019, 63, 101-108. [CrossRef] [PubMed]

47. Matsha, T.; Prince, Y.; Davids, S.; Chikte, U.; Erasmus, R.; Kengne, A.; Davison, G. Oral Microbiome Signatures in Diabetes Mellitus and Periodontal Disease. J. Dent. Res. 2020, 99, 658-665. [CrossRef] [PubMed]

48. Borrell, L.; Burt, B.; Taylor, G. Prevalence and Trends in Periodontitis in the USA: From the NHANES III to the NHANES, 1988 to 2000. J. Dent. Res. 2005, 84, 924-930. [CrossRef]

49. Loe, H. Periodontal Disease: The sixth complication of diabetes mellitus. Diabetes Care 1993, 16, 329-334. [CrossRef]

50. Hotamisligil, G.S. Inflammation and metabolic disorders. Nature 2006, 444, 860-867. [CrossRef]

51. Xiao, E.; Mattos, M.; Vieira, G.H.A.; Chen, S.; Corrêa, J.; Wu, Y.; Albiero, M.L.; Bittinger, K.; Graves, D.T. Diabetes Enhances IL-17 Expression and Alters the Oral Microbiome to Increase Its Pathogenicity. Cell Host Microbe 2017, 22, 120.e4-128.e4. [CrossRef]

52. Casarin, R.C.V.; Barbagallo, A.; Meulman, T.; Santos, V.R.; Sallum, E.A.; Nociti, F.; Duarte, P.M.; Casati, M.Z.; Gonçalves, R.B. Subgingival biodiversity in subjects with uncontrolled type-2 diabetes and chronic periodontitis. J. Periodontal. Res. 2013, 48, 30-36. [CrossRef] [PubMed]

53. Blasco-Baque, V.; Garidou, L.; Pomié, C.; Escoula, Q.; Loubieres, P.; Le Gall-David, S.; Lemaitre, M.; Nicolas, S.; Klopp, P.; Waget, A.; et al. Periodontitis induced byPorphyromonas gingivalisdrives periodontal microbiota dysbiosis and insulin resistance via an impaired adaptive immune response. Gut 2016, 66, 872-885. [CrossRef] 
54. Amano, A. Disruption of epithelial barrier and impairment of cellular function by Porphyromonas gingivalis. Front. Biosci. 2007, 12, 3965-3974. [CrossRef] [PubMed]

55. Cani, P.D.; Amar, J.; Iglesias, M.A.; Poggi, M.; Knauf, C.; Bastelica, D.; Neyrinck, A.; Fava, F.; Tuohy, K.; Chabo, C.; et al. Metabolic Endotoxemia Initiates Obesity and Insulin Resistance. Diabetes 2007, 56, 1761-1772. [CrossRef] [PubMed]

56. Mealey, B.L.; Oates, T.W.; American Academy of Periodontology. Diabetes Mellitus and Periodontal Diseases. J. Periodontol. 2006, 77, 1289-1303. [CrossRef] [PubMed]

57. Sharma, N.; Bhatia, S.; Sodhi, A.S.; Batra, N. Oral microbiome and health. AIMS Microbiol. 2018, 4, 42-66. [CrossRef]

58. Joshipura, K.J.; Muñoz-Torres, F.J.; Morou-Bermudez, E.; Patel, R.P. Over-the-counter mouthwash use and risk of prediabetes/diabetes. Nitric Oxide 2017, 71, 14-20. [CrossRef]

59. Turnbaugh, P.; Ridaura, V.K.; Faith, J.J.; Rey, F.E.; Knight, R.; Gordon, J.I. The Effect of Diet on the Human Gut Microbiome: A Metagenomic Analysis in Humanized Gnotobiotic Mice. Sci. Transl. Med. 2009, 1, 6ra14. [CrossRef] [PubMed]

60. Turnbaugh, P.J.; Ley, R.E.; Mahowald, M.A.; Magrini, V.; Mardis, E.R.; Gordon, J.I. An obesity-associated gut microbiome with increased capacity for energy harvest. Nat. Cell Biol. 2006, 444, 1027-1031. [CrossRef]

61. Khor, B.; Snow, M.; Herrman, E.; Ray, N.; Mansukhani, K.; Patel, K.; Said-Al-Naief, N.; Maier, T.; Machida, C. Interconnections between the Oral and Gut Microbiomes: Reversal of Microbial Dysbiosis and the Balance between Systemic Health and Disease. Microorganisms 2021, 9, 496. [CrossRef]

62. Le Chatelier, E.; Nielsen, T.; Qin, J.; Prifti, E.; Hildebrand, F.; Falony, G.; Almeida, M.; Arumugam, M.; Batto, J.-M.; Kennedy, S.; et al. Richness of human gut microbiome correlates with metabolic markers. Nature 2013, 500, 541-546. [CrossRef]

63. Wu, Y.; Chi, X.; Zhang, Q.; Chen, F.; Deng, X. Characterization of the salivary microbiome in people with obesity. PeerJ 2018, 6, e4458. [CrossRef] [PubMed]

64. Ley, R.; Turnbaugh, P.J.; Klein, S.; Gordon, J.I. Human gut microbes associated with obesity. Nature 2006, $444,1022-1023$. [CrossRef] [PubMed]

65. Haffajee, A.D.; Socransky, S.S. Relation of body mass index, periodontitis andTannerella forsythia. J. Clin. Periodontol. 2009, 36, 89-99. [CrossRef] [PubMed]

66. Maciel, S.S.; Feres, M.; Gonçalves, T.E.D.; Zimmermann, G.S.; Da Silva, H.D.P.; Figueiredo, L.C.; Duarte, P.M. Does obesity influence the subgingival microbiota composition in periodontal health and disease? J. Clin. Periodontol. 2016, 43, 1003-1012. [CrossRef] [PubMed]

67. Zeigler, C.C.; Persson, G.R.; Wondimu, B.; Marcus, C.; Sobko, T.; Modéer, T. Microbiota in the Oral Subgingival Biofilm Is Associated with Obesity in Adolescence. Obes. 2012, 20, 157-164. [CrossRef] [PubMed]

68. Thomas, C.; Minty, M.; Canceill, T.; Loubières, P.; Azalbert, V.; Tercé, F.; Champion, C.; Burcelin, R.; Barthet, P.; LaurencinDalicieux, S.; et al. Obesity Drives an Oral Microbiota Signature of Female Patients with Periodontitis: A Pilot Study. Diagnostics 2021, 11, 745. [CrossRef] [PubMed]

69. GBD 2017 Causes of Death Collaborators. Global, regional, and national age-sex-specific mortality for 282 causes of death in 195 countries and territories, 1980-2017: A systematic analysis for the Global Burden of Disease Study 2017. Lancet 2018, 392, 1736-1788. [CrossRef]

70. Roth, G.A.; Forouzanfar, M.H.; Moran, A.E.; Barber, R.; Nguyen, G.; Feigin, V.L.; Naghavi, M.; Mensah, G.A.; Murray, C.J. Demographic and Epidemiologic Drivers of Global Cardiovascular Mortality. N. Engl. J. Med. 2015, 372, 1333-1341. [CrossRef]

71. World Health Organization (WHO). Cardiovascular Diseases (CVDs). Available online: https://www.who.int/News-Room/ Fact-Sheets/Detail/Cardiovascular-Diseases-(Cvds) (accessed on 15 June 2021).

72. Joseph, P.; Leong, D.; McKee, M.; Anand, S.S.; Schwalm, J.-D.; Teo, K.; Mente, A.; Yusuf, S. Reducing the Global Burden of Cardiovascular Disease, Part 1. Circ. Res. 2017, 121, 677-694. [CrossRef]

73. Virani, S.S.; Alonso, A.; Aparicio, H.J.; Benjamin, E.J.; Bittencourt, M.S.; Callaway, C.W.; Carson, A.P.; Chamberlain, A.M.; Cheng, S.; Delling, F.N.; et al. Heart Disease and Stroke Statistics-2021 Update: A Report From the American Heart Association. Circulation 2021, 143, e254-e743. [CrossRef]

74. Mesa, F.; Magan-Fernandez, A.; Castellino, G.; Chianetta, R.; Nibali, L.; Rizzo, M. Periodontitis and mechanisms of cardiometabolic risk: Novel insights and future perspectives. Biochim. Biophys. Acta (BBA) Mol. Basis Dis. 2019, 1865, 476-484. [CrossRef]

75. Pietiäinen, M.; Liljestrand, J.M.; Kopra, E.; Pussinen, P.J. Mediators between oral dysbiosis and cardiovascular diseases. Eur. J. Oral Sci. 2018, 126, 26-36. [CrossRef] [PubMed]

76. Libby, P.; Buring, J.E.; Badimon, L.; Hansson, G.K.; Deanfield, J.; Bittencourt, M.S.; Tokgözoğlu, L.; Lewis, E.F. Atherosclerosis. Nat. Rev. Dis. Prim. 2019, 5, 56. [CrossRef] [PubMed]

77. Mattila, K.J.; Nieminen, M.S.; Valtonen, V.V.; Rasi, V.P.; Kesaniemi, Y.A.; Syrjala, S.L.; Jungell, P.S.; Isoluoma, M.; Hietaniemi, K.; Jokinen, M.J. Association between dental health and acute myocardial infarction. Br. Med. J. 1989, 298, 779-781. [CrossRef] [PubMed]

78. Tonetti, M.S.; Van Dyke, T.E. Periodontitis and atherosclerotic cardiovascular disease: Consensus report of the Joint EFP/AAP Workshop on Periodontitis and Systemic Diseases. J. Clin. Periodontol. 2013, 40, S24-S29. [CrossRef]

79. Lockhart, P.B.; Bolger, A.F.; Papapanou, P.N.; Osinbowale, O.; Trevisan, M.; Levison, M.E.; Taubert, K.A.; Newburger, J.W.; Gornik, H.L.; Gewitz, M.H.; et al. Periodontal Disease and Atherosclerotic Vascular Disease: Does the Evidence Support an Independent Association? Circulation 2012, 125, 2520-2544. [CrossRef] 
80. Sanz, M.; Del Castillo, A.M.; Jepsen, S.; Juanatey, J.R.G.; D’Aiuto, F.; Bouchard, P.; Chapple, I.; Dietrich, T.; Gotsman, I.; Graziani, F.; et al. Periodontitis and cardiovascular diseases: Consensus report. J. Clin. Periodontol. 2020, 47, 268-288. [CrossRef]

81. Larvin, H.; Kang, J.; Aggarwal, V.R.; Pavitt, S.; Wu, J. Risk of incident cardiovascular disease in people with periodontal disease: A systematic review and meta-analysis. Clin. Exp. Dent. Res. 2021, 7, 109-122. [CrossRef]

82. Tonetti, M.S.; D'Aiuto, F.; Nibali, L.; Donald, A.; Storry, C.; Parkar, M.; Suvan, J.; Hingorani, A.; Vallance, P.; Deanfield, J. Treatment of Periodontitis and Endothelial Function. N. Engl. J. Med. 2007, 356, 911-920. [CrossRef]

83. Roca-Millan, E.; Gonzalez-Navarro, B.; Sabater-Recolons, M.; Mari-Roig, A.; Jane-Salas, E.; Lopez-Lopez, J. Periodontal treatment on patients with cardiovascular disease: Systematic review and meta-analysis. Medicina Oral Patología Oral y Cirugia Bucal 2018, 23, e681-e690. [CrossRef]

84. Sharma, S.; Sridhar, S.; McIntosh, A.; Messow, C.-M.; Aguilera, E.M.; Del Pinto, R.; Pietropaoli, D.; Gorska, R.; Siedlinski, M.; Maffia, P.; et al. Periodontal therapy and treatment of hypertension-alternative to the pharmacological approach. A systematic review and meta-analysis. Pharmacol. Res. 2021, 166, 105511. [CrossRef]

85. Lobo, M.G.; Schmidt, M.M.; Lopes, R.D.; Dipp, T.; Feijó, I.P.; Schmidt, K.E.; Gazeta, C.A.; Azeredo, M.L.; Markoski, M.; Pellanda, L.C.; et al. Treating periodontal disease in patients with myocardial infarction: A randomized clinical trial. Eur. J. Intern. Med. 2020, 71, 76-80. [CrossRef]

86. Mahendra, J.; Mahendra, L.; Nagarajan, A.; Mathew, K. Prevalence of eight putative periodontal pathogens in atherosclerotic plaque of coronary artery disease patients and comparing them with noncardiac subjects: A case-control study. Indian J. Dent. Res. 2015, 26, 189-195. [CrossRef]

87. Pavlic, V.; Peric, D.; Kalezic, I.S.; Madi, M.; Bhat, S.G.; Brkic, Z.; Staletovic, D. Identification of Periopathogens in Atheromatous Plaques Obtained from Carotid and Coronary Arteries. BioMed Res. Int. 2021, 2021, 1-7. [CrossRef] [PubMed]

88. Figuero, E.; Sánchez, M.C.; Cuesta-Frechoso, S.; Tejerina, J.M.; Del Castro, J.A.; Gutiérrez, J.M.; Herrera, D.; Sanz, M. Detection of Periodontal Bacteria in Atheromatous Plaque by Nested Polymerase Chain Reaction. J. Periodontol. 2011, 82, $1469-1477$. [CrossRef] [PubMed]

89. Chhibber-Goel, J.; Singhal, V.; Bhowmik, D.; Vivek, R.; Parakh, N.; Bhargava, B.; Sharma, A. Linkages between oral commensal bacteria and atherosclerotic plaques in coronary artery disease patients. NPJ Biofilms Microbiomes 2016, 2, 7. [CrossRef] [PubMed]

90. Straka, M.; Kazar, J.; Pijak, M.R.; Gasparovic, J.; Wsolova, L.; Mongiellova, V. The importance of the presence of aggregatibacter actinomycetemcomitans in sulcus gingivalis of patients with cardiovascular diseases. Med. Sci. Monit. 2011, 17, CR646-CR649. [CrossRef]

91. Ghizoni, J.S.; Taveira, L.A.D.A.; Garlet, G.; Ghizoni, M.F.; Pereira, J.; Dionisio, T.; Brozoski, D.T.; dos Santos, C.F.; Sant'Ana, A.C.P. Increased levels of Porphyromonas gingivalis are associated with ischemic and hemorrhagic cerebrovascular disease in humans: An in vivo study. J. Appl. Oral Sci. 2012, 20, 104-112. [CrossRef]

92. Koren, O.; Spor, A.; Felin, J.; Fak, F.; Stombaugh, J.; Tremaroli, V.; Behre, C.J.; Knight, R.; Fagerberg, B.; Ley, R.E.; et al. Human oral, gut, and plaque microbiota in patients with atherosclerosis. Proc. Natl. Acad. Sci. USA 2011, 108, 4592-4598. [CrossRef]

93. Mougeot, J.-L.C.; Stevens, C.B.; Paster, B.J.; Brennan, M.T.; Lockhart, P.B.; Mougeot, F.K.B. Porphyromonas gingivalis is the most abundant species detected in coronary and femoral arteries. J. Oral Microbiol. 2017, 9, 1281562. [CrossRef]

94. Oliveira, F.A.F.; Forte, C.P.F.; Silva, P.G.D.B.; Lopes, C.B.; Montenegro, R.; dos Santos, Â.K.C.R.; Sobrinho, C.R.M.R.; Mota, M.; Sousa, F.B.; Alves, A.P.N.N. Molecular Analysis of Oral Bacteria in Heart Valve of Patients with Cardiovascular Disease by Real-Time Polymerase Chain Reaction. Medicine 2015, 94, e2067. [CrossRef]

95. Pereira, R.B.; Vasquez, E.C.; Stefanon, I.; Meyrelles, S.S. Oral P. gingivalis infection alters the vascular reactivity in healthy and spontaneously atherosclerotic mice. Lipids Health Dis. 2011, 10, 80. [CrossRef] [PubMed]

96. Miyauchi, S.; Maekawa, T.; Aoki, Y.; Miyazawa, H.; Tabeta, K.; Nakajima, T.; Yamazaki, K. Oral infection with Porphyromonas gingivalis and systemic cytokine profile in C57BL/6.KOR-ApoEshl mice. J. Periodontal. Res. 2011, 47, 402-408. [CrossRef] [PubMed]

97. Hokamura, K.; Inaba, H.; Nakano, K.; Nomura, R.; Yoshioka, H.; Taniguchi, K.; Ooshima, T.; Wada, K.; Amano, A.; Umemura, K. Molecular analysis of aortic intimal hyperplasia caused byPorphyromonas gingivalisinfection in mice with endothelial damage. J. Periodontal. Res. 2010, 45, 337-344. [CrossRef]

98. Chukkapalli, S.S.; Rivera, M.F.; Velsko, I.M.; Lee, J.-Y.; Chen, H.; Zheng, D.; Bhattacharyya, I.; Gangula, P.R.; Lucas, A.R.; Kesavalu, L. Invasion of Oral and Aortic Tissues by Oral Spirochete Treponema denticola in ApoE- / - Mice Causally Links Periodontal Disease and Atherosclerosis. Infect. Immun. 2014, 82, 1959-1967. [CrossRef] [PubMed]

99. Lee, S.H.; Lee, H.-R.; Jun, H.-K.; Kim, H.-D.; Choi, B.-K. Fusobacterium nucleatum GroEL induces risk factors of atherosclerosis in human microvascular endothelial cells and ApoE-/ - mice. Mol. Oral Microbiol. 2011, 27, 109-123. [CrossRef]

100. Velsko, I.M.; Chukkapalli, S.; Rivera-Kweh, M.F.; Zheng, D.; Aukhil, I.; Lucas, A.R.; Larjava, H.; Kesavalu, L. Periodontal Pathogens Invade Gingiva and Aortic Adventitia and Elicit Inflammasome Activation in $\alpha v \beta 6$ Integrin-Deficient Mice. Infect. Immun. 2015, 83, 4582-4593. [CrossRef]

101. Chukkapalli, S.S.; Velsko, I.M.; Rivera-Kweh, M.F.; Zheng, D.; Lucas, A.R.; Kesavalu, L. Polymicrobial Oral Infection with Four Periodontal Bacteria Orchestrates a Distinct Inflammatory Response and Atherosclerosis in ApoEnull Mice. PLoS ONE 2015, 10, e0143291. [CrossRef]

102. Farrugia, C.; Stafford, G.P.; Potempa, J.; Wilkinson, R.; Chen, Y.; Murdoch, C.; Widziolek, M. Mechanisms of vascular damage by systemic dissemination of the oral pathogen Porphyromonas gingivalis. FEBS J. 2021, 288, 1479-1495. [CrossRef] 
103. Schenkein, H.A.; Loos, B.G. Inflammatory mechanisms linking periodontal diseases to cardiovascular diseases. J. Clin. Periodontol. 2013, 40, S51-S69. [CrossRef]

104. Pussinen, P.J.; Vilkuna-Rautiainen, T.; Alfthan, G.; Palosuo, T.; Jauhiainen, M.; Sundvall, J.; Vesanen, M.; Mattila, K.; Asikainen, S. Severe Periodontitis Enhances Macrophage Activation via Increased Serum Lipopolysaccharide. Arter. Thromb. Vasc. Biol. 2004, 24, 2174-2180. [CrossRef] [PubMed]

105. Caúla, A.L.; Lira-Junior, R.; Tinoco, E.M.B.; Fischer, R.G. The effect of periodontal therapy on cardiovascular risk markers: A 6-month randomized clinical trial. J. Clin. Periodontol. 2014, 41, 875-882. [CrossRef] [PubMed]

106. Zeigler, C.C.; Wondimu, B.; Marcus, C.; Modéer, T. Pathological periodontal pockets are associated with raised diastolic blood pressure in obese adolescents. BMC Oral Health 2015, 15, 41. [CrossRef] [PubMed]

107. Stoll, L.L.; Denning, G.M.; Weintraub, N.L. Potential Role of Endotoxin as a Proinflammatory Mediator of Atherosclerosis. Arter. Thromb. Vasc. Biol. 2004, 24, 2227-2236. [CrossRef]

108. Amar, S.; Gokce, N.; Morgan, S.; Loukideli, M.; Van Dyke, T.E.; Vita, J.A. Periodontal Disease Is Associated with Brachial Artery Endothelial Dysfunction and Systemic Inflammation. Arter. Thromb. Vasc. Biol. 2003, 23, 1245-1249. [CrossRef]

109. Kallio, K.E.; Hyvärinen, K.; Kovanen, P.T.; Jauhiainen, M.; Pussinen, P. Very low density lipoproteins derived from periodontitis patients facilitate macrophage activation via lipopolysaccharide function. Metabolism 2013, 62, 661-668. [CrossRef] [PubMed]

110. Rufail, M.L.; Schenkein, H.A.; Koertge, T.E.; Best, A.; Barbour, S.E.; Tew, J.G.; Van Antwerpen, R. Atherogenic lipoprotein parameters in patients with aggressive periodontitis. J. Periodontal. Res. 2007, 42, 495-502. [CrossRef] [PubMed]

111. Rizzo, M.; Banach, M.; Montalto, G.; Mikhailidis, D.P. Editorial Lipid-lowering therapies and achievement of LDL-cholesterol targets. Arch. Med. Sci. 2012, 4, 598-600. [CrossRef]

112. Chotirmall, S.H.; Gellatly, S.; Budden, K.F.; Mac Aogáin, M.; Shukla, S.; Wood, D.L.; Hugenholtz, P.; Pethe, K.; Hansbro, P.M. Microbiomes in respiratory health and disease: An Asia-Pacific perspective. Respirol. 2017, 22, 240-250. [CrossRef] [PubMed]

113. Bassis, C.M.; Erb-Downward, J.R.; Dickson, R.P.; Freeman, C.M.; Schmidt, T.M.; Young, V.B.; Beck, J.M.; Curtis, J.L.; Huffnagle, G.B. Analysis of the upper respiratory tract microbiotas as the source of the lung and gastric microbiotas in healthy individuals. mBio 2015, 6, e00037-15. [CrossRef]

114. Shukla, S.; Budden, K.F.; Neal, R.; Hansbro, P.M. Microbiome effects on immunity, health and disease in the lung. Clin. Transl. Immunol. 2017, 6, e133. [CrossRef] [PubMed]

115. Huffnagle, G.B.; Dickson, R.P.; Lukacs, N.W. The respiratory tract microbiome and lung inflammation: A two-way street. Mucosal Immunol. 2017, 10, 299-306. [CrossRef]

116. Global Initiative for Chronic Obstructive Lung Disease. Global Strategy for the Diagnosis, Management and Prevention of Chronic Obstructive Pulmonary Disease: 2019 Report. 2019. Available online: https://Goldcopd.Org/Gold-Reports/ (accessed on 15 June 2021).

117. Budden, K.F.; Shukla, S.; Rehman, S.F.; Bowerman, K.; Keely, S.; Hugenholtz, P.; Armstrong-James, D.; Adcock, I.M.; Chotirmall, S.H.; Chung, K.F.; et al. Functional effects of the microbiota in chronic respiratory disease. Lancet Respir. Med. 2019, 7, 907-920. [CrossRef]

118. Sethi, S.; Murphy, T. Infection in the Pathogenesis and Course of Chronic Obstructive Pulmonary Disease. N. Engl. J. Med. 2008, 359, 2355-2365. [CrossRef]

119. Górska, K.; Paplińska-Goryca, M.; Nejman-Gryz, P.; Goryca, K.; Krenke, R. Eosinophilic and Neutrophilic Airway Inflammation in the Phenotyping of Mild-to-Moderate Asthma and Chronic Obstructive Pulmonary Disease. COPD J. Chronic Obstr. Pulm. Dis. 2016, 14, 181-189. [CrossRef]

120. Ko, F.W.; Chan, K.P.; Hui, D.; Goddard, J.R.; Shaw, J.; Reid, D.; Yang, I. Acute exacerbation of COPD. Respirology 2016, 21, 1152-1165. [CrossRef]

121. Moghoofei, M.; Jamalkandi, S.A.; Moein, M.; Salimian, J.; Ahmadi, A. Bacterial infections in acute exacerbation of chronic obstructive pulmonary disease: A systematic review and meta-analysis. Infection 2019, 48, 19-35. [CrossRef]

122. Tan, L.; Wang, H.; Li, C.; Pan, Y. 16S rDNA-based metagenomic analysis of dental plaque and lung bacteria in patients with severe acute exacerbations of chronic obstructive pulmonary disease. J. Periodontal. Res. 2014, 49, 760-769. [CrossRef]

123. Zeng, X.-T.; Tu, M.-L.; Liu, D.-Y.; Zheng, D.; Zhang, J.; Leng, W. Periodontal Disease and Risk of Chronic Obstructive Pulmonary Disease: A Meta-Analysis of Observational Studies. PLoS ONE 2012, 7, e46508. [CrossRef] [PubMed]

124. Takeuchi, K.; Matsumoto, K.; Furuta, M.; Fukuyama, S.; Takeshita, T.; Ogata, H.; Suma, S.; Shibata, Y.; Shimazaki, Y.; Hata, J.; et al. Periodontitis Is Associated with Chronic Obstructive Pulmonary Disease. J. Dent. Res. 2019, 98, 534-540. [CrossRef] [PubMed]

125. Kucukcoskun, M.; Baser, U.; Oztekin, G.; Kiyan, E.; Yalcin, F. Initial Periodontal Treatment for Prevention of Chronic Obstructive Pulmonary Disease Exacerbations. J. Periodontol. 2013, 84, 863-870. [CrossRef] [PubMed]

126. Zhou, X.; Han, J.; Liu, Z.; Song, Y.; Wang, Z.; Sun, Z. Effects of periodontal treatment on lung function and exacerbation frequency in patients with chronic obstructive pulmonary disease and chronic periodontitis: A 2-year pilot randomized controlled trial J. Clin. Periodontol. 2014, 41, 564-572. [CrossRef] [PubMed]

127. Hayata, M.; Watanabe, N.; Tamura, M.; Kamio, N.; Tanaka, H.; Nodomi, K.; Miya, C.; Nakayama, E.; Ueda, K.; Ogata, Y.; et al. The Periodontopathic Bacterium Fusobacterium nucleatum Induced Proinflammatory Cytokine Production by Human Respiratory Epithelial Cell Lines and in the Lower Respiratory Organs in Mice. Cell. Physiol. Biochem. 2019, 53, 49-61. [CrossRef] [PubMed] 
128. Li, Q.; Tan, L.; Wang, H.; Kou, Y.; Shi, X.; Zhang, S.; Pan, Y. Fusobacterium nucleatum Interaction with Pseudomonas aeruginosa Induces Biofilm-Associated Antibiotic Tolerance via Fusobacterium Adhesin A. ACS Infect. Dis. 2020, 6, 1686-1696. [CrossRef] [PubMed]

129. Li, Q.; Wang, H.; Tan, L.; Zhang, S.; Lin, L.; Tang, X.; Pan, Y. Oral Pathogen Fusobacterium nucleatum Coaggregates with Pseudomonas aeruginosa to Modulate the Inflammatory Cytotoxicity of Pulmonary Epithelial Cells. Front. Cell. Infect. Microbiol. 2021, 11, 643913. [CrossRef]

130. Marouf, N.; Cai, W.; Said, K.N.; Daas, H.; Diab, H.; Chinta, V.R.; Hssain, A.A.; Nicolau, B.; Sanz, M.; Tamimi, F. Association between periodontitis and severity of COVID-19 infection: A case-control study. J. Clin. Periodontol. 2021, 48, 483-491. [CrossRef]

131. Takahashi, Y.; Watanabe, N.; Kamio, N.; Yokoe, S.; Suzuki, R.; Sato, S.; Iinuma, T.; Imai, K. Expression of the SARS-CoV-2 Receptor ACE2 and Proinflammatory Cytokines Induced by the Periodontopathic Bacterium Fusobacterium nucleatum in Human Respiratory Epithelial Cells. Int. J. Mol. Sci. 2021, 22, 1352. [CrossRef]

132. Mercado, F.; Marshall, R.I.; Klestov, A.C.; Bartold, P. Is there a relationship between rheumatoid arthritis and periodontal disease? J. Clin. Periodontol. 2000, 27, 267-272. [CrossRef]

133. Smolen, J.S.; Aletaha, D.; McInnes, I.B. Rheumatoid arthritis. Lancet 2016, 388, 2023-2038. [CrossRef]

134. Anquetil, F.; Clavel, C.; Offer, G.; Serre, G.; Sebbag, M. IgM and IgA Rheumatoid Factors Purified from Rheumatoid Arthritis Sera Boost the Fc Receptor- and Complement-Dependent Effector Functions of the Disease-Specific Anti-Citrullinated Protein Autoantibodies. J. Immunol. 2015, 194, 3664-3674. [CrossRef] [PubMed]

135. McInnes, I.B.; Schett, G. The Pathogenesis of Rheumatoid Arthritis. N. Engl. J. Med. 2011, 365, 2205-2219. [CrossRef] [PubMed]

136. Nielen, M.M.J.; Van Schaardenburg, D.; Reesink, H.W.; Van De Stadt, R.J.; Van Der Horst-Bruinsma, I.E.; De Koning, M.H.M.T.; Habibuw, M.R.; Vandenbroucke, J.P.; Dijkmans, B.A.C. Specific autoantibodies precede the symptoms of rheumatoid arthritis: A study of serial measurements in blood donors. Arthritis Rheum. 2004, 50, 380-386. [CrossRef]

137. Arkema, E.V.; Goldstein, B.L.; Robinson, W.; Sokolove, J.; Wagner, C.; Malspeis, S.; Rosner, B.; Grodstein, F.; Karlson, E.W.; Costenbader, K.H. Anti-citrullinated peptide autoantibodies, human leukocyte antigen shared epitope and risk of future rheumatoid arthritis: A nested case-control study. Arthritis Res. Ther. 2013, 15, R159. [CrossRef] [PubMed]

138. Muller, S.; Radic, M. Citrullinated Autoantigens: From Diagnostic Markers to Pathogenetic Mechanisms. Clin. Rev. Allergy Immunol. 2015, 49, 232-239. [CrossRef] [PubMed]

139. De Pablo, P.; Dietrich, T.; McAlindon, T.E. Association of periodontal disease and tooth loss with rheumatoid arthritis in the US population. J. Rheumatol. 2007, 35, 70-76.

140. Volkov, M.; Van Schie, K.A.; Van Der Woude, D. Autoantibodies and B Cells: The ABC of rheumatoid arthritis pathophysiology. Immunol. Rev. 2019, 294, 148-163. [CrossRef]

141. Eriksson, K.; Fei, G.; Lundmark, A.; Benchimol, D.; Lee, L.; Hu, Y.O.O.; Kats, A.; Saevarsdottir, S.; Catrina, A.I.; Klinge, B.; et al. Periodontal Health and Oral Microbiota in Patients with Rheumatoid Arthritis. J. Clin. Med. 2019, 8, 630. [CrossRef]

142. Fuggle, N.R.; Smith, T.O.; Kaul, A.; Sofat, N. Hand to Mouth: A Systematic Review and Meta-Analysis of the Association between Rheumatoid Arthritis and Periodontitis. Front. Immunol. 2016, 7, 80. [CrossRef]

143. Jepsen, S.; Caton, J.G.; Albandar, J.M.; Bissada, N.F.; Bouchard, P.; Cortellini, P.; Demirel, K.; de Sanctis, M.; Ercoli, C.; Fan, J.; et al. Periodontal manifestations of systemic diseases and developmental and acquired conditions: Consensus report of workgroup 3 of the 2017 World Workshop on the Classification of Periodontal and Peri-Implant Diseases and Conditions. J. Clin. Periodontol. 2018, 45, S219-S229. [CrossRef]

144. Silvestre-Rangil, J.; Bagan, L.; Silvestre, F.J.; Bagán, J.V. Oral manifestations of rheumatoid arthritis. A cross-sectional study of 73 patients. Clin. Oral Investig. 2016, 20, 2575-2580. [CrossRef]

145. Schwenzer, A.; Quirke, A.; Marzeda, A.; Wong, A.; Montgomery, A.B.; Sayles, H.R.; Eick, S.; Gawron, K.; Chomyszyn-Gajewska, M.; Łazarz-Bartyzel, K.; et al. Association of Distinct Fine Specificities of Anti-Citrullinated Peptide Antibodies with Elevated Immune Responses to Prevotella intermedia in a Subgroup of Patients with Rheumatoid Arthritis and Periodontitis. Arthritis Rheumatol. 2017, 69, 2303-2313. [CrossRef] [PubMed]

146. Mikuls, T.R.; Payne, J.; Yu, F.; Thiele, G.; Reynolds, R.J.; Cannon, G.W.; Markt, J.; McGowan, D.; Kerr, G.S.; Redman, R.S.; et al. Periodontitis andPorphyromonas gingivalisin Patients with Rheumatoid Arthritis. Arthritis Rheumatol. 2014, 66, 1090-1100. [CrossRef]

147. Wegner, N.; Wait, R.; Sroka, A.; Eick, S.; Nguyen, K.-A.; Lundberg, K.; Kinloch, A.; Culshaw, S.; Potempa, J.; Venables, P.J. Peptidylarginine deiminase from Porphyromonas gingivalis citrullinates human fibrinogen and $\alpha$-enolase: Implications for autoimmunity in rheumatoid arthritis. Arthritis Rheum. 2010, 62, 2662-2672. [CrossRef] [PubMed]

148. Kharlamova, N.; Jiang, X.; Sherina, N.; Potempa, B.; Israelsson, L.; Quirke, A.-M.; Eriksson, K.; Yucel-Lindberg, T.; Venables, P.J.; Potempa, J.; et al. Antibodies toPorphyromonas gingivalisIndicate Interaction Between Oral Infection, Smoking, and Risk Genes in Rheumatoid Arthritis Etiology. Arthritis Rheumatol. 2016, 68, 604-613. [CrossRef]

149. Johansson, L.; Sherina, N.; Kharlamova, N.; Potempa, B.; Larsson, B.; Israelsson, L.; Potempa, J.; Rantapää-Dahlqvist, S.; Lundberg, K. Concentration of antibodies against Porphyromonas gingivalis is increased before the onset of symptoms of rheumatoid arthritis. Arthritis Res. 2016, 18, 1-10. [CrossRef]

150. Konig, M.F.; Abusleme, L.; Reinholdt, J.; Palmer, R.J.; Teles, R.P.; Sampson, K.; Rosen, A.; Nigrovic, P.A.; Sokolove, J.; Giles, J.T.; et al. Aggregatibacter actinomycetemcomitans-induced hypercitrullination links periodontal infection to autoimmunity in rheumatoid arthritis. Sci. Transl. Med. 2016, 8, 369ra176. [CrossRef] [PubMed] 
151. Tong, Y.; Zheng, L.; Qing, P.; Zhao, H.; Li, Y.; Su, L.; Zhang, Q.; Zhao, Y.; Luo, Y.; Liu, Y. Oral Microbiota Perturbations Are Linked to High Risk for Rheumatoid Arthritis. Front. Cell. Infect. Microbiol. 2020, 9, 475. [CrossRef] [PubMed]

152. Feldmann, M.; Brennan, F.M.; Maini, R.N. Role of Cytokines in Rheumatoid Arthritis. Annu. Rev. Immunol. 1996, 14, 397-440. [CrossRef]

153. Armitage, G.C. Bi-directional relationship between pregnancy and periodontal disease. Periodontology 2000 2013, 61, 160-176. [CrossRef]

154. Figueiredo, C.S.D.A.; Rosalem, C.G.C.; Cantanhede, A.L.C.; Thomaz, É.B.A.F.; Da Cruz, M.C.F.N. Systemic alterations and their oral manifestations in pregnant women. J. Obstet. Gynaecol. Res. 2017, 43, 16-22. [CrossRef] [PubMed]

155. Miranda, L.A.; Islabão, A.G.; Fischer, R.G.; Figueredo, C.M.; Oppermann, R.V.; Gustafsson, A. Decreased Interleukin-1 $\beta$ and Elastase in the Gingival Crevicular Fluid of Individuals Undergoing Anti-Inflammatory Treatment for Rheumatoid Arthritis. J. Periodontol. 2007, 78, 1612-1619. [CrossRef] [PubMed]

156. Sakaguchi, W.; To, M.; Yamamoto, Y.; Inaba, K.; Yakeishi, M.; Saruta, J.; Fuchida, S.; Hamada, N.; Tsukinoki, K. Detection of anti-citrullinated protein antibody (ACPA) in saliva for rheumatoid arthritis using DBA mice infected with Porphyromonas gingivalis. Arch. Oral Biol. 2019, 108, 104510. [CrossRef] [PubMed]

157. Teles, F.; Wang, Y.; Hajishengallis, G.; Hasturk, H.; Marchesan, J.T. Impact of systemic factors in shaping the periodontal microbiome. Periodontology 2000 2021, 85, 126-160. [CrossRef]

158. Figuero, E.; Carrillo-De-Albornoz, A.; Herrera, D.; Bascones-Martínez, A. Gingival changes during pregnancy: I. Influence of hormonal variations on clinical and immunological parameters. J. Clin. Periodontol. 2010, 37, 220-229. [CrossRef]

159. Balan, P.; Chong, Y.S.; Umashankar, S.; Swarup, S.; Loke, W.M.; Lopez, V.; He, H.G.; Seneviratne, C.J. Keystone Species in Pregnancy Gingivitis: A Snapshot of Oral Microbiome during Pregnancy and Postpartum Period. Front. Microbiol. $2018,9,2360$. [CrossRef]

160. Sanz, M.; Kornman, K.; Working Group 3 of the Joint EFP/AAP Workshop. Periodontitis and adverse pregnancy outcomes: Consensus report of the Joint EFP/AAP Workshop on Periodontitis and Systemic Diseases. J. Periodontol. 2013, 84, S164-S169. [CrossRef]

161. A Boggess, K. Maternal periodontal disease is associated with an increased risk for preeclampsia. Obstet. Gynecol. 2003, 101, 227-231. [CrossRef]

162. Han, Y.W.; Fardini, Y.; Chen, C.; Iacampo, K.G.; Peraino, V.A.; Shamonki, J.M.; Redline, R.W. Term Stillbirth Caused by Oral Fusobacterium nucleatum. Obstet. Gynecol. 2010, 115, 442-445. [CrossRef]

163. He, M.; Migliori, A.R.; Lauro, P.; Sung, C.J.; Pinar, H. Perinatal Mortality Associated with Positive Postmortem Cultures for Common Oral Flora. Infect. Dis. Obstet. Gynecol. 2017, 2017. [CrossRef] [PubMed]

164. Komine-Aizawa, S.; Aizawa, S.; Hayakawa, S. Periodontal diseases and adverse pregnancy outcomes. J. Obstet. Gynaecol. Res. 2019, 45, 5-12. [CrossRef]

165. Cobb, C.M.; Kelly, P.J.; Williams, K.B.; Babbar, S.; Angolkar, M.; Derman, R. The oral microbiome and adverse pregnancy outcomes. Int. J. Women's Health 2017, ume 9, 551-559. [CrossRef]

166. Aagaard, K.; Ma, J.; Antony, K.M.; Ganu, R.; Petrosino, J.; Versalovic, J. The Placenta Harbors a Unique Microbiome. Sci. Transl. Med. 2014, 6, 237ra65. [CrossRef] [PubMed]

167. Fischer, L.A.; Demerath, E.; Bittner-Eddy, P.; Costalonga, M. Placental colonization with periodontal pathogens: The potential missing link. Am. J. Obstet. Gynecol. 2019, 221, 383.e3-392.e3. [CrossRef]

168. Fardini, Y.; Chung, P.; Dumm, R.; Joshi, N.; Han, Y.W. Transmission of Diverse Oral Bacteria to Murine Placenta: Evidence for the Oral Microbiome as a Potential Source of Intrauterine Infection. Infect. Immun. 2010, 78, 1789-1796. [CrossRef] [PubMed]

169. Vanterpool, S.F.; Been, J.V.; Houben, M.L.; Nikkels, P.G.J.; De Krijger, R.R.; Zimmermann, L.J.I.; Kramer, B.W.; Progulske-Fox, A.; Reyes, L. Porphyromonas gingivalis within Placental Villous Mesenchyme and Umbilical Cord Stroma Is Associated with Adverse Pregnancy Outcome. PLoS ONE 2016, 11, e0146157. [CrossRef]

170. Barak, S.; Oettinger-Barak, O.; Machtei, E.E.; Sprecher, H.; Ohel, G. Evidence of Periopathogenic Microorganisms in Placentas of Women with Preeclampsia. J. Periodontol. 2007, 78, 670-676. [CrossRef]

171. Ramadugu, K.; Bhaumik, D.; Luo, T.; Gicquelais, R.; Lee, K.; Stafford, E.; Marrs, C.; Neiswanger, K.; McNeil, D.; Marazita, M.; et al. Maternal Oral Health Influences Infant Salivary Microbiome. J. Dent. Res. 2021, 100, 58-65. [CrossRef]

172. Sartor, R.B. Mechanisms of Disease: Pathogenesis of Crohn's disease and ulcerative colitis. Nat. Clin. Pract. Gastroenterol. Hepatol. 2006, 3, 390-407. [CrossRef]

173. Jang, H.-J.; Kang, B.; Choe, B.-H. The difference in extraintestinal manifestations of inflammatory bowel disease for children and adults. Transl. Pediatr. 2019, 8, 4-15. [CrossRef]

174. Mortada, I.; Leone, A.; Geagea, A.G.; Mortada, R.; Matar, C.; Rizzo, M.; Hussein, I.H.; Massade, L.; Jurjus, A. Oral manifestations of inflammatory bowel disease. J. Boil. Regul. Homeost. Agents 2017, 31, 817-821.

175. Thomas, C.; Dimmock, M.; de Saint-Joseph, C.G.; Barres, B.; Paul, C.; Cousty, S.; Laurencin-Dalicieux, S. How Oral Specialists Can Help Diagnose and Manage Extra-Digestive Inflammatory Bowel Disease Complications. Case Rep. Gastroenterol. 2021, 15, 276-281. [CrossRef] [PubMed]

176. Muhvić-Urek, M.; Tomac-Stojmenović, M.; Mijandrušić-Sinčić, B. Oral pathology in inflammatory bowel disease. World J. Gastroenterol. 2016, 22, 5655-5667. [CrossRef] [PubMed] 
177. Manichanh, C.; Rigottier-Gois, L.; Bonnaud, E.; Gloux, K.; Pelletier, E.; Frangeul, L.; Nalin, R.; Jarrin, C.; Chardon, P.; Marteau, P.; et al. Reduced diversity of faecal microbiota in Crohn's disease revealed by a metagenomic approach. Gut 2006, 55, 205-211. [CrossRef] [PubMed]

178. Ott, S.J. Reduction in diversity of the colonic mucosa associated bacterial microflora in patients with active inflammatory bowel disease. Gut 2004, 53, 685-693. [CrossRef]

179. Prosberg, M.; Bendtsen, F.; Vind, I.; Petersen, A.M.; Gluud, L.L. The association between the gut microbiota and the inflammatory bowel disease activity: A systematic review and meta-analysis. Scand. J. Gastroenterol. 2016, 51, 1407-1415. [CrossRef]

180. She, Y.-Y.; Kong, X.-B.; Ge, Y.-P.; Liu, Z.-Y.; Chen, J.-Y.; Jiang, J.-W.; Jiang, H.; Fang, S.-L. Periodontitis and inflammatory bowel disease: A meta-analysis. BMC Oral Health 2020, 20, 1-11. [CrossRef]

181. Zhang, Y.; Qiao, D.; Chen, R.; Zhu, F.; Gong, J.; Yan, F. The Association between Periodontitis and Inflammatory Bowel Disease: A Systematic Review and Meta-analysis. BioMed Res. Int. 2021, 2021, 1-8. [CrossRef]

182. Said, H.S.; Suda, W.; Nakagome, S.; Chinen, H.; Oshima, K.; Kim, S.; Kimura, R.; Iraha, A.; Ishida, H.; Fujita, J.; et al. Dysbiosis of Salivary Microbiota in Inflammatory Bowel Disease and Its Association with Oral Immunological Biomarkers. DNA Res. 2013, 21, 15-25. [CrossRef]

183. Schmidt, J.; Weigert, M.; Leuschner, C.; Hartmann, H.; Raddatz, D.; Haak, R.; Mausberg, R.; Kottmann, T.; Schmalz, G.; Ziebolz, D. Active matrix metalloproteinase- 8 and periodontal bacteria-interlink between periodontitis and inflammatory bowel disease? J. Periodontol. 2018, 89, 699-707. [CrossRef] [PubMed]

184. Xun, Z.; Zhang, Q.; Xu, T.; Chen, N.; Chen, F. Dysbiosis and Ecotypes of the Salivary Microbiome Associated with Inflammatory Bowel Diseases and the Assistance in Diagnosis of Diseases Using Oral Bacterial Profiles. Front. Microbiol. 2018, 9, 1136. [CrossRef] [PubMed]

185. Brito, F.; Zaltman, C.; Carvalho, A.T.; Fischer, R.G.; Persson, R.; Gustafsson, A.; Figueredo, C.M. Subgingival microflora in inflammatory bowel disease patients with untreated periodontitis. Eur. J. Gastroenterol. Hepatol. 2013, 25, 239-245. [CrossRef]

186. Van Dyke, T.E.; Dowell, V.R., Jr.; Offenbacher, S.; Snyder, W.; Hersh, T. Potential role of microorganisms isolated from periodontal lesions in the pathogenesis of inflammatory bowel disease. Infect. Immun. 1986, 53, 671-677. [CrossRef]

187. Zhang, T.; Kayani, M.U.R.; Hong, L.; Zhang, C.; Zhong, J.; Wang, Z.; Chen, L. Dynamics of the Salivary Microbiome During Different Phases of Crohn's Disease. Front. Cell. Infect. Microbiol. 2020, 10, 544704. [CrossRef] [PubMed]

188. Kitamoto, S.; Nagao-Kitamoto, H.; Hein, R.; Schmidt, T.; Kamada, N. The Bacterial Connection between the Oral Cavity and the Gut Diseases. J. Dent. Res. 2020, 99, 1021-1029. [CrossRef]

189. Li, B.; Ge, Y.; Cheng, L.; Zeng, B.; Yu, J.; Peng, X.; Zhao, J.; Li, W.; Ren, B.; Li, M.; et al. Oral bacteria colonize and compete with gut microbiota in gnotobiotic mice. Int. J. Oral Sci. 2019, 11, 10. [CrossRef]

190. Huh, J.-W.; Roh, T.-Y. Opportunistic detection of Fusobacterium nucleatum as a marker for the early gut microbial dysbiosis. BMC Microbiol. 2020, 20, 1-17. [CrossRef]

191. Kitamoto, S.; Nagao-Kitamoto, H.; Jiao, Y.; Gillilland, M.G.; Hayashi, A.; Imai, J.; Sugihara, K.; Miyoshi, M.; Brazil, J.C.; Kuffa, P.; et al. The Intermucosal Connection between the Mouth and Gut in Commensal Pathobiont-Driven Colitis. Cell 2020, 182, 447.e14-462.e14. [CrossRef]

192. Nakajima, M.; Arimatsu, K.; Kato, T.; Matsuda, Y.; Minagawa, T.; Takahashi, N.; Ohno, H.; Yamazaki, K. Oral Administration of P. gingivalis Induces Dysbiosis of Gut Microbiota and Impaired Barrier Function Leading to Dissemination of Enterobacteria to the Liver. PLoS ONE 2015, 10, e0134234. [CrossRef]

193. Kobayashi, R.; Ogawa, Y.; Hashizume-Takizawa, T.; Kurita-Ochiai, T. Oral bacteria affect the gut microbiome and intestinal immunity. Pathog. Dis. 2020, 78, 024. [CrossRef]

194. Atarashi, K.; Suda, W.; Luo, C.; Kawaguchi, T.; Motoo, I.; Narushima, S.; Kiguchi, Y.; Yasuma, K.; Watanabe, E.; Tanoue, T.; et al. Ectopic colonization of oral bacteria in the intestine drives TH1 cell induction and inflammation. Science 2017, 358, 359-365. [CrossRef]

195. Allen, M.; Wang, X.; Burgess, J.D.; Watzlawik, J.; Serie, D.J.; Younkin, C.S.; Nguyen, T.; Malphrus, K.G.; Lincoln, S.; Carrasquillo, M.M.; et al. Conserved brain myelination networks are altered in Alzheimer's and other neurodegenerative diseases. Alzheimer's Dement. 2017, 14, 352-366. [CrossRef] [PubMed]

196. Alzheimer's Association 2018 Alzheimer's disease facts and figures. Alzheimer's Dement. 2018, 14, 367-429. [CrossRef]

197. Condello, C.; Stöehr, J. A $\beta$ propagation and strains: Implications for the phenotypic diversity in Alzheimer's disease. Neurobiol. Dis. 2018, 109, 191-200. [CrossRef]

198. Shao, Q.-H.; Zhang, X.-L.; Yang, P.-F.; Yuan, Y.-H.; Chen, N.-H. Amyloidogenic proteins associated with neurodegenerative diseases activate the NLRP3 inflammasome. Int. Immunopharmacol. 2017, 49, 155-160. [CrossRef] [PubMed]

199. Rosenberg, A.; Ngandu, T.; Rusanen, M.; Antikainen, R.; Bäckman, L.; Havulinna, S.; Hänninen, T.; Laatikainen, T.; Lehtisalo, J.; Levälahti, E.; et al. Multidomain lifestyle intervention benefits a large elderly population at risk for cognitive decline and dementia regardless of baseline characteristics: The FINGER trial. Alzheimer's Dement. 2018, 14, 263-270. [CrossRef]

200. Harding, A.; Gonder, U.; Robinson, S.; Crean, S.; Singhrao, S.K. Exploring the Association between Alzheimer's Disease, Oral Health, Microbial Endocrinology and Nutrition. Front. Aging Neurosci. 2017, 9, 398. [CrossRef]

201. Chen, C.-K.; Wu, Y.-T.; Chang, Y.-C. Association between chronic periodontitis and the risk of Alzheimer's disease: A retrospective, population-based, matched-cohort study. Alzheimer's Res. Ther. 2017, 9, 1-7. [CrossRef] [PubMed] 
202. Kamer, A.; Craig, R.G.; Niederman, R.; Fortea, J.; de Leon, M. Periodontal disease as a possible cause for Alzheimer's disease. Periodontology 2000 2020, 83, 242-271. [CrossRef]

203. Liu, X.-X.; Bin Jiao, B.; Liao, X.-X.; Guo, L.-N.; Yuan, Z.-H.; Wang, X.; Xiao, X.-W.; Zhang, X.-Y.; Tang, B.-S.; Shen, L. Analysis of Salivary Microbiome in Patients with Alzheimer's Disease. J. Alzheimer's Dis. 2019, 72, 633-640. [CrossRef]

204. Sparks Stein, P.; Steffen, M.J.; Smith, C.; Jicha, G.; Ebersole, J.L.; Abner, E.; Dawson, D. Serum antibodies to periodontal pathogens are a risk factor for Alzheimer's disease. Alzheimer's Dement. 2012, 8, 196-203. [CrossRef]

205. Maitre, Y.; Micheneau, P.; Delpierre, A.; Mahalli, R.; Guerin, M.; Amador, G.; Denis, F. Did the Brain and Oral Microbiota Talk to Each Other? A Review of the Literature. J. Clin. Med. 2020, 9, 3876. [CrossRef]

206. Liccardo, D.; Marzano, F.; Carraturo, F.; Guida, M.; Femminella, G.D.; Bencivenga, L.; Agrimi, J.; Addonizio, A.; Melino, I.; Valletta, A.; et al. Potential Bidirectional Relationship Between Periodontitis and Alzheimer's Disease. Front. Physiol. 2020, 11, 683. [CrossRef]

207. Fang, W.-L.; Jiang, M.-J.; Gu, B.-B.; Wei, Y.-M.; Fan, S.-N.; Liao, W.; Zheng, Y.-Q.; Liao, S.-W.; Xiong, Y.; Li, Y.; et al. Tooth loss as a risk factor for dementia: Systematic review and meta-analysis of 21 observational studies. BMC Psychiatry 2018, 18, 1-11. [CrossRef] [PubMed]

208. Olsen, I.; Singhrao, S.K. Can oral infection be a risk factor for Alzheimer's disease? J. Oral Microbiol. 2015, 7, 29143. [CrossRef] [PubMed]

209. Lukiw, W.J. Bacteroides fragilis Lipopolysaccharide and Inflammatory Signaling in Alzheimer's Disease. Front. Microbiol. 2016, 7, 1544. [CrossRef]

210. Zhang, J.; Yu, C.; Zhang, X.; Chen, H.; Dong, J.; Lu, W.; Song, Z.; Zhou, W. Porphyromonas gingivalis lipopolysaccharide induces cognitive dysfunction, mediated by neuronal inflammation via activation of the TLR4 signaling pathway in C57BL/6 mice. J. Neuroinflammation 2018, 15, 1-14. [CrossRef] [PubMed]

211. Poole, S.; Singhrao, S.K.; Chukkapalli, S.; Rivera, M.; Velsko, I.; Kesavalu, L.; Crean, S. Active Invasion of Porphyromonas gingivalis and Infection-Induced Complement Activation in ApoE-/- Mice Brains. J. Alzheimer's Dis. 2014, 43, 67-80. [CrossRef]

212. Ilievski, V.; Zuchowska, P.K.; Green, S.J.; Toth, P.; Ragozzino, M.E.; Le, K.; Aljewari, H.W.; O’Brien-Simpson, N.; Reynolds, E.C.; Watanabe, K. Chronic oral application of a periodontal pathogen results in brain inflammation, neurodegeneration and amyloid beta production in wild type mice. PLoS ONE 2018, 13, e0204941. [CrossRef]

213. Wu, Z.; Ni, J.; Liu, Y.; Teeling, J.; Takayama, F.; Collcutt, A.; Ibbett, P.; Nakanishi, H. Cathepsin B plays a critical role in inducing Alzheimer's disease-like phenotypes following chronic systemic exposure to lipopolysaccharide from Porphyromonas gingivalis in mice. Brain Behav. Immun. 2017, 65, 350-361. [CrossRef]

214. Schwahn, C.; Frenzel, S.; Holtfreter, B.; Van der Auwera, S.; Pink, C.; Bülow, R.; Friedrich, N.; Völzke, H.; Biffar, R.; Kocher, T.; et al. Effect of periodontal treatment on preclinical Alzheimer's disease-Results of a trial emulation approach. Alzheimer's Dement. 2021, alz.12378. [CrossRef]

215. American Psychiatric Association. Diagnostic and Statistical Manual of Mental Disorders, 5th ed; American Psychiatric Association: Washington, DC, USA, 2013; ISBN 978-0-89042-555-8.

216. Catalá-López, F.; Ridao, M.; Hurtado, I.; Núñez-Beltrán, A.; Gènova-Maleras, R.; Alonso-Arroyo, A.; Tobías, A.; AleixandreBenavent, R.; Catalá, M.A.; Tabarés-Seisdedos, R. Prevalence and comorbidity of autism spectrum disorder in Spain: Study protocol for a systematic review and meta-analysis of observational studies. Syst. Rev. 2019, 8, 1-7. [CrossRef]

217. Gandhi, R.P.; Klein, U. Autism Spectrum Disorders: An Update on Oral Health Management. J. Evid. Based Dent. Pract. 2014, 14 (Suppl. S1), S115-S126. [CrossRef]

218. Lu, Y.-Y.; Wei, I.-H.; Huang, C.-C. Dental health-A challenging problem for a patient with autism spectrum disorder. Gen. Hosp. Psychiatry 2013, 35, 214.e1-214.e3. [CrossRef] [PubMed]

219. Delli, K.; Reichart, P.; Bornstein, M.M.; Livas, C. Management of children with autism spectrum disorder in the dental setting: Concerns, behavioural approaches and recommendations. Medicina Oral Patología Oral y Cirugia Bucal 2013, 18, e862-e868. [CrossRef] [PubMed]

220. Qiao, Y.; Wu, M.; Feng, Y.; Zhou, Z.; Chen, L.; Chen, F. Alterations of oral microbiota distinguish children with autism spectrum disorders from healthy controls. Sci. Rep. 2018, 8, 1-12. [CrossRef] [PubMed]

221. Kong, X.; Liu, J.; Cetinbas, M.; Sadreyev, R.; Koh, M.; Huang, H.; Adeseye, A.; He, P.; Zhu, J.; Russell, H.; et al. New and Preliminary Evidence on Altered Oral and Gut Microbiota in Individuals with Autism Spectrum Disorder (ASD): Implications for ASD Diagnosis and Subtyping Based on Microbial Biomarkers. Nutrients 2019, 11, 2128. [CrossRef]

222. Olsen, I.; Hicks, S. Oral microbiota and autism spectrum disorder (ASD). J. Oral Microbiol. 2020, 12, 1702806. [CrossRef]

223. Aghbari, S.M.H.; Abushouk, A.I.; Attia, A.; Elmaraezy, A.; Menshawy, A.; Ahmed, M.S.; Elsaadany, B.A.; Ahmed, E.M. Malignant transformation of oral lichen planus and oral lichenoid lesions: A meta-analysis of 20095 patient data. Oral Oncol. 2017, 68, 92-102. [CrossRef]

224. Buffington, S.A.; Di Prisco, G.V.; Auchtung, T.A.; Ajami, N.J.; Petrosino, J.F.; Costa-Mattioli, M. Microbial Reconstitution Reverses Maternal Diet-Induced Social and Synaptic Deficits in Offspring. Cell 2016, 165, 1762-1775. [CrossRef]

225. Kumar, H.; Sharma, B. Minocycline ameliorates prenatal valproic acid induced autistic behaviour, biochemistry and blood brain barrier impairments in rats. Brain Res. 2016, 1630, 83-97. [CrossRef]

226. Wang, X.; Yang, J.; Zhang, H.; Yu, J.; Yao, Z. Oral probiotic administration during pregnancy prevents autism-related behaviors in offspring induced by maternal immune activation via anti-inflammation in mice. Autism Res. 2019, 12, 576-588. [CrossRef] 
227. Lin, D.; Yang, L.; Wen, L.; Lu, H.; Chen, Q.; Wang, Z. Crosstalk between the oral microbiota, mucosal immunity, and the epithelial barrier regulates oral mucosal disease pathogenesis. Mucosal Immunol. 2021, 1-12. [CrossRef]

228. Freire, M.; Nelson, K.; Edlund, A. The Oral Host-Microbial Interactome: An Ecological Chronometer of Health? Trends Microbiol. 2021, 29, 551-561. [CrossRef] [PubMed]

229. Gupta, S.; Jawanda, M. Oral lichen planus: An update on etiology, pathogenesis, clinical presentation, diagnosis and management. Indian J. Dermatol. 2015, 60, 222-229. [CrossRef] [PubMed]

230. Li, Y.; Wang, K.; Zhang, B.; Tu, Q.; Yao, Y.; Cui, B.; Ren, B.; He, J.; Shen, X.; Van Nostrand, J.D.; et al. Salivary mycobiome dysbiosis and its potential impact on bacteriome shifts and host immunity in oral lichen planus. Int. J. Oral Sci. 2019, 11, 1-10. [CrossRef] [PubMed]

231. Scully, C.; Felix, D.H. Oral medicine - Update for the dental practitioner Aphthous and other common ulcers. Br. Dent. J. 2005, 199, 259-264. [CrossRef]

232. Yang, Z.; Cui, Q.; An, R.; Wang, J.; Song, X.; Shen, Y.; Wang, M.; Xu, H. Comparison of microbiomes in ulcerative and normal mucosa of recurrent aphthous stomatitis (RAS)-affected patients. BMC Oral Health 2020, 20, 1-8. [CrossRef]

233. Kim, Y.-J.; Choi, Y.S.; Baek, K.J.; Yoon, S.-H.; Park, H.K.; Choi, Y. Mucosal and salivary microbiota associated with recurrent aphthous stomatitis. BMC Microbiol. 2016, 16, 1-10. [CrossRef]

234. Yu, F.; Wang, Q.Q.; Li, M.; Cheng, Y.-H.; Cheng, Y.-S.L.; Zhou, Y.; Yang, X.; Zhang, F.; Ge, X.; Zhao, B.; et al. Dysbiosis of saliva microbiome in patients with oral lichen planus. BMC Microbiol. 2020, 20,1-12. [CrossRef]

235. Johnson, N.; Jayasekara, P.; Amarasinghe, A.A.H.K. Squamous cell carcinoma and precursor lesions of the oral cavity: Epidemiology and aetiology. Periodontology 2000 2011, 57, 19-37. [CrossRef]

236. Schwabe, R.F.; Jobin, C. The microbiome and cancer. Nat. Rev. Cancer 2013, 13, 800-812. [CrossRef]

237. Lim, Y.; Fukuma, N.; Totsika, M.; Kenny, L.; Morrison, M.; Punyadeera, C. The Performance of an Oral Microbiome Biomarker Panel in Predicting Oral Cavity and Oropharyngeal Cancers. Front. Cell. Infect. Microbiol. 2018, 8, 267. [CrossRef]

238. Yang, S.-F.; Huang, H.-D.; Fan, W.-L.; Jong, Y.-J.; Chen, M.-K.; Huang, C.-N.; Kuo, Y.-L.; Hung, S.-I.; Su, S.-C. Compositional and functional variations of oral microbiota associated with the mutational changes in oral cancer. Oral Oncol. 2018, 77, 1-8. [CrossRef] [PubMed]

239. Yang, C.-Y.; Yeh, Y.-M.; Yu, H.-Y.; Chin, C.-Y.; Hsu, C.-W.; Liu, H.; Huang, P.-J.; Hu, S.-N.; Liao, C.-T.; Chang, K.-P.; et al. Oral Microbiota Community Dynamics Associated with Oral Squamous Cell Carcinoma Staging. Front. Microbiol. $2018,9,862$. [CrossRef] [PubMed]

240. Amer, A.; Galvin, S.; Healy, C.; Moran, G.P. The Microbiome of Potentially Malignant Oral Leukoplakia Exhibits Enrichment for Fusobacterium, Leptotrichia, Campylobacter, and Rothia Species. Front. Microbiol. 2017, 8, 2391. [CrossRef] [PubMed]

241. Hashimoto, K.; Shimizu, D.; Hirabayashi, S.; Ueda, S.; Miyabe, S.; Oh-Iwa, I.; Nagao, T.; Shimozato, K.; Nomoto, S. Changes in oral microbial profiles associated with oral squamous cell carcinoma vs leukoplakia. J. Investig. Clin. Dent. 2019, 10, e12445. [CrossRef]

242. Monsarrat, P.; Blaizot, A.; Kemoun, P.; Ravaud, P.; Nabet, C.; Sixou, M.; Vergnes, J.-N. Clinical research activity in periodontal medicine: A systematic mapping of trial registers. J. Clin. Periodontol. 2016, 43, 390-400. [CrossRef] [PubMed]

243. Zalewska, A.; Waszkiewicz, N.; López-Pintor, R.M. The Use of Saliva in the Diagnosis of Oral and Systemic Diseases. Dis. Markers 2019, 2019, 1-2. [CrossRef]

244. Huang, N.; Pérez, P.; Kato, T.; Mikami, Y.; Okuda, K.; Gilmore, R.C.; Conde, C.D.; Gasmi, B.; Stein, S.; Beach, M.; et al. SARS-CoV-2 infection of the oral cavity and saliva. Nat. Med. 2021, 27, 892-903. [CrossRef]

245. Kapoor, P.; Chowdhry, A.; Kharbanda, O.P.; Popli, D.B.; Gautam, K.; Saini, V. Exploring salivary diagnostics in COVID-19: A scoping review and research suggestions. BDJ Open 2021, 7, 1-10. [CrossRef] [PubMed]

246. Javaid, M.A.; Ahmed, A.S.; Durand, R.; Tran, S.D. Saliva as a diagnostic tool for oral and systemic diseases. J. Oral Biol. Craniofacial Res. 2016, 6, 67-76. [CrossRef]

247. Wei, F.; Lin, C.-C.; Joon, A.; Feng, Z.; Troche, G.; Lira, M.E.; Chia, D.; Mao, M.; Ho, C.-L.; Su, W.-C.; et al. Noninvasive SalivabasedEGFRGene Mutation Detection in Patients with Lung Cancer. Am. J. Respir. Crit. Care Med. 2014, 190, 1117-1126. [CrossRef]

248. Pu, D.; Liang, H.; Wei, F.; Akin, D.; Feng, Z.; Yan, Q.; Li, Y.; Zhen, Y.; Xu, L.; Dong, G.; et al. Evaluation of a novel saliva-based epidermal growth factor receptor mutation detection for lung cancer: A pilot study. Thorac. Cancer 2016, 7, 428-436. [CrossRef]

249. Kaczor-Urbanowicz, K.E.; Wei, F.; Rao, S.L.; Kim, J.; Shin, H.; Cheng, J.; Tu, M.; Wong, D.T.; Kim, Y. Clinical validity of saliva and novel technology for cancer detection. Biochim. Biophys. Acta (BBA) Bioenerg. 2019, 1872, 49-59. [CrossRef] [PubMed]

250. Zhang, C.-Z.; Cheng, X.-Q.; Li, J.-Y.; Zhang, P.; Yi, P.; Xu, X.; Zhou, X.-D. Saliva in the diagnosis of diseases. Int. J. Oral Sci. 2016, 8, 133-137. [CrossRef] [PubMed]

251. Mannoor, M.S.; Tao, H.; Clayton, J.D.; Sengupta, A.; Kaplan, D.L.; Naik, R.R.; Verma, N.; Omenetto, F.G.; McAlpine, M. Graphene-based wireless bacteria detection on tooth enamel. Nat. Commun. 2012, 3, 763. [CrossRef]

252. Wong, D.T. Towards a simple, saliva-based test for the detection of oral cancer. Expert Rev. Mol. Diagn. 2006, 6, 267-272. [CrossRef]

253. Jiang, S.; Zeng, J.; Zhou, X.; Li, Y. Drug Resistance and Gene Transfer Mechanisms in Respiratory/Oral Bacteria. J. Dent. Res. 2018, 97, 1092-1099. [CrossRef]

254. Belibasakis, G.N.; Bostanci, N.; Marsh, P.D.; Zaura, E. Applications of the oral microbiome in personalized dentistry. Arch. Oral Biol. 2019, 104, 7-12. [CrossRef] 
255. Jepsen, K.; Jepsen, S. Antibiotics/antimicrobials: Systemic and local administration in the therapy of mild to moderately advanced periodontitis. Periodontology 2000 2016, 71, 82-112. [CrossRef] [PubMed]

256. Cieplik, F.; Jakubovics, N.S.; Buchalla, W.; Maisch, T.; Hellwig, E.; Al-Ahmad, A. Resistance Toward Chlorhexidine in Oral Bacteria-Is There Cause for Concern? Front. Microbiol. 2019, 10, 587. [CrossRef] [PubMed]

257. Carra, M.C.; Detzen, L.; Kitzmann, J.; Woelber, J.P.; Ramseier, C.A.; Bouchard, P. Promoting behavioural changes to improve oral hygiene in patients with periodontal diseases: A systematic review. J. Clin. Periodontol. 2020, 47, 72-89. [CrossRef] [PubMed]

258. Chapple, I.L.C.; Van Der Weijden, F.; Doerfer, C.; Herrera, D.; Shapira, L.; Polak, D.; Madianos, P.; Louropoulou, A.; Machtei, E.; Donos, N.; et al. Primary prevention of periodontitis: Managing gingivitis. J. Clin. Periodontol. 2015, 42, S71-S76. [CrossRef] [PubMed]

259. Isacco, C.G.; Ballini, A.; De Vito, D.; Nguyen, K.C.D.; Cantore, S.; Bottalico, L.; Quagliuolo, L.; Boccellino, M.; Di Domenico, M.; Santacroce, L.; et al. Rebalancing the Oral Microbiota as an Efficient Tool in Endocrine, Metabolic and Immune Disorders. Endocr. Metab. Immune Disord. Drug Targets 2021, 21, 777-784. [CrossRef] [PubMed]

260. Rosier, B.; Marsh, P.; Mira, A. Resilience of the Oral Microbiota in Health: Mechanisms That Prevent Dysbiosis. J. Dent. Res. 2018, 97, 371-380. [CrossRef]

261. Fang, D.; Shi, D.; Lv, L.; Gu, S.; Wu, W.; Chen, Y.; Guo, J.; Li, A.; Hu, X.; Guo, F.; et al. Bifidobacterium pseudocatenulatum LI09 and Bifidobacterium catenulatum LI10 attenuate D-galactosamine-induced liver injury by modifying the gut microbiota. Sci. Rep. 2017, 7, 1-13. [CrossRef]

262. Schneeberger, M.; Everard, A.; Gómez-Valadés, A.G.; Matamoros, S.; Ramírez, S.; Delzenne, N.; Gomis, R.; Claret, M.; Cani, P.D. Akkermansia muciniphila inversely correlates with the onset of inflammation, altered adipose tissue metabolism and metabolic disorders during obesity in mice. Sci. Rep. 2015, 5, 16643. [CrossRef] [PubMed]

263. Pérez, Á.M.; Neef, A.; Sanz, Y. Bifidobacterium pseudocatenulatum CECT 7765 Reduces Obesity-Associated Inflammation by Restoring the Lymphocyte-Macrophage Balance and Gut Microbiota Structure in High-Fat Diet-Fed Mice. PLoS ONE 2015, 10, e0126976. [CrossRef]

264. Teughels, W.; Newman, M.; Coucke, W.; Haffajee, A.; Van Der Mei, H.; Haake, S.K.; Schepers, E.; Cassiman, J.-J.; Van Eldere, J.; Van Steenberghe, D.; et al. Guiding Periodontal Pocket Recolonization: A Proof of Concept. J. Dent. Res. 2007, 86, 1078-1082. [CrossRef]

265. Rosier, B.T.; Moya-Gonzalvez, E.M.; Corell-Escuin, P.; Mira, A. Isolation and Characterization of Nitrate-Reducing Bacteria as Potential Probiotics for Oral and Systemic Health. Front. Microbiol. 2020, 11, 555465. [CrossRef]

266. Golub, L.M.; Lee, H.-M. Periodontal therapeutics: Current host-modulation agents and future directions. Periodontology 2000 2020, 82, 186-204. [CrossRef]

267. Preshaw, P.M. Host modulation therapy with anti-inflammatory agents. Periodontology 2000 2018, 76, 131-149. [CrossRef] [PubMed]

268. Tonetti, M.S.; Chapple, I.L.C.; Working Group 3 of the Seventh European Workshop on Periodontology. Biological approaches to the development of novel periodontal therapies-Consensus of the Seventh European Workshop on Periodontology. J. Clin. Periodontol. 2011, 38, 114-118. [CrossRef] [PubMed]

269. Gorr, S.-U.; Abdolhosseini, M. Antimicrobial peptides and periodontal disease. J. Clin. Periodontol. 2011, 38, 126-141. [CrossRef]

270. Jourdain, M.; Velard, F.; Pierrard, L.; Sergheraert, J.; Gangloff, S.C.; Braux, J. Cationic antimicrobial peptides and periodontal physiopathology: A systematic review. J. Periodontal. Res. 2019, 54, 589-600. [CrossRef] [PubMed]

271. Batool, F.; Stutz, C.; Petit, C.; Benkirane-Jessel, N.; Delpy, E.; Zal, F.; Leize-Zal, E.; Huck, O. A therapeutic oxygen carrier isolated from Arenicola marina decreased P. gingivalis induced inflammation and tissue destruction. Sci. Rep. 2020, 10, 1-14. [CrossRef]

272. Martinon, P.; Fraticelli, L.; Giboreau, A.; Dussart, C.; Bourgeois, D.; Carrouel, F. Nutrition as a Key Modifiable Factor for Periodontitis and Main Chronic Diseases. J. Clin. Med. 2021, 10, 197. [CrossRef]

273. Balta, M.G.; Loos, B.G.; Nicu, E.A. Emerging Concepts in the Resolution of Periodontal Inflammation: A Role for Resolvin E1. Front. Immunol. 2017, 8, 1682. [CrossRef] [PubMed]

274. Sulijaya, B.; Takahashi, N.; Yamazaki, K. Host modulation therapy using anti-inflammatory and antioxidant agents in periodontitis: A review to a clinical translation. Arch. Oral Biol. 2019, 105, 72-80. [CrossRef] [PubMed]

275. Lee, C.J.; Iyer, G.; Liu, Y.; Kalyani, R.R.; Bamba, N.; Ligon, C.B.; Varma, S.; Mathioudakis, N. The effect of vitamin D supplementation on glucose metabolism in type 2 diabetes mellitus: A systematic review and meta-analysis of intervention studies. J. Diabetes Complicat. 2017, 31, 1115-1126. [CrossRef]

276. Sacerdote, A.; Dave, P.; Lokshin, V.; Bahtiyar, G. Type 2 Diabetes Mellitus, Insulin Resistance, and Vitamin D. Curr. Diabetes Rep. 2019, 19, 101. [CrossRef] [PubMed]

277. Issa, C.M. Vitamin D and Type 2 Diabetes Mellitus. In Ultraviolet Light in Human Health, Diseases and Environment; Advances in Experimental Medicine and Biology; Ahmad, S., Ed.; Springer: Cham, Switzerland, 2017; Volume 996, pp. 193-205. [CrossRef]

278. Lips, P.; Eekhoff, M.; van Schoor, N.; Oosterwerff, M.; de Jongh, R.; Krul-Poel, Y.; Simsek, S. Vitamin D and type 2 diabetes. J. Steroid Biochem. Mol. Biol. 2017, 173, 280-285. [CrossRef] [PubMed]

279. Antonoglou, G.N.; Knuuttila, M.; Niemela, O.; Raunio, T.; Karttunen, R.; Vainio, O.M.; Hedberg, P.; Ylostalo, P.; Tervonen, T. Low serum level of 1,25(OH)2 D is associated with chronic periodontitis. J. Periodontal. Res. 2015, 50, 274-280. [CrossRef]

280. Rhodes, J.M.; Subramanian, S.; Laird, E.; Griffin, G.; Kenny, R.A. Perspective: Vitamin D deficiency and COVID-19 severityPlausibly linked by latitude, ethnicity, impacts on cytokines, ACE2 and thrombosis. J. Intern. Med. 2021, 289, 97-115. [CrossRef]

281. Mangin, M.; Sinha, R.; Fincher, K. Inflammation and vitamin D: The infection connection. Inflamm. Res. 2014, 63, 803-819. [CrossRef] 
282. Pilz, S.; Kienreich, K.; Rutters, F.; De Jongh, R.; Van Ballegooijen, A.J.; Grübler, M.R.; Tomaschitz, A.; Dekker, J.M. Role of Vitamin D in the Development of Insulin Resistance and Type 2 Diabetes. Curr. Diabetes Rep. 2012, 13, 261-270. [CrossRef]

283. Patel, M. Dental caries vaccine: Are we there yet? Lett. Appl. Microbiol. 2020, 70, 2-12. [CrossRef]

284. Malla, M.A.; Dubey, A.; Kumar, A.; Yadav, S.; Hashem, A.; Allah, E.F.A. Exploring the Human Microbiome: The Potential Future Role of Next-Generation Sequencing in Disease Diagnosis and Treatment. Front. Immunol. 2019, 9, 2868. [CrossRef]

285. Myneni, S.R.; Brocavich, K.; Wang, H.H. Biological strategies for the prevention of periodontal disease: Probiotics and vaccines. Periodontology 2000 2020, 84, 161-175. [CrossRef] [PubMed]

286. Falcao, A.; Bullón, P. A review of the influence of periodontal treatment in systemic diseases. Periodontology 2000 2019, 79, 117-128. [CrossRef]

287. Jeffcoat, M.K.; Jeffcoat, R.L.; Gladowski, P.A.; Bramson, J.B.; Blum, J.J. Impact of Periodontal Therapy on General Health. Am. J. Prev. Med. 2014, 47, 166-174. [CrossRef]

288. Bernabé, E.; Marcenes, W.; Hernandez, C.R.; Bailey, J.; Abreu, L.G.; Alipour, V.; Amini, S.; Arabloo, J.; Arefi, Z.; Arora, A.; et al. Global, Regional, and National Levels and Trends in Burden of Oral Conditions from 1990 to 2017: A Systematic Analysis for the Global Burden of Disease 2017 Study. J. Dent. Res. 2020, 99, 362-373. [CrossRef] [PubMed]

289. Vos, T.; Abajobir, A.A.; Abate, K.H.; Abbafati, C.; Abbas, K.M.; Abd-Allah, F.; Abdulkader, R.S.; Abdulle, A.M.; Abebo, T.A.; Abera, S.F.; et al. Global, regional, and national incidence, prevalence, and years lived with disability for 328 diseases and injuries for 195 countries, 1990-2016: A systematic analysis for the Global Burden of Disease Study 2016. Lancet 2017, 390, 1211-1259. [CrossRef] 